\title{
4
}

\section{Inflammatory Bowel Disease G-Protein Coupled Receptors (GPCRs) Expression Profiling with Microfluidic Cards}

\author{
Nathalie Taquet ${ }^{1}$, Claude Philippe ${ }^{1}$, \\ Jean-Marie Reimund ${ }^{2,3}$ and Christian D. Muller ${ }^{1}$ \\ ${ }^{1}$ Laboratoire d'Innovation Thérapeutique UMR CNRS 7200, \\ Faculté de Pharmacie, Université de Strasbourg, \\ ${ }^{2} \mathrm{CHU}$ de Caen, Service d'Hépato-Gastro-Entérologie et Nutrition \\ ${ }^{3}$ Université de Caen Basse-Normandie, EA 3919, SFR ICORE, UFR de Médecine
}

France

\section{Introduction}

Crohn's disease (CD) and chronic ulcerative colitis (UC) are considered as two distinct forms of inflammatory bowel disease (IBD). In IBDs, the first clinical signs of disease begin typically between adolescence and the third decade of life (Andres \& Friedman 1999; Baldassano \& Piccoli 1999). CD is a non-specific granulomatous inflammatory disease affecting the lower end of the ileum and often involving the colon and other parts of the intestinal tract (Podolsky 2002). CD was first reported by B. Crohn and his colleagues in 1932 and called Regional Enteritis (Matsuura et al. 1993). CD is diagnosed in four patients per 100000 in the Northern Europe and the incidence and prevalence is rising (Elson et al. 1995). UC is a chronic disease of unknown etiology characterized by inflammation of the mucosa and sub-mucosa of the rectum (altimes) with a continuous extension to upper parts of the colon without healthy mucosa between inflammatory mucosa, which can be limited to the rectum (proctitis) to the colon below the lefts angle (left colitis), beyond the left angle (extensive colitis) or affect all the colon (pancolitis). UC is mostly characterized by bloody diarrhea. UC may have a prevalence of 100 case per 100000 population in Northern Europe (Satsangi et al. 1996)

The causes of $C D$ and UC remain to be clarified. However, genetic factors in combination with environmental factors are suspected to be involved in the pathogenesis of Crohn's disease (Baker et al. 1981; Podolsky 2002). Inadequate or prolonged activation of the intestinal immune system plays an important role in the pathophysiology of chronic mucosal inflammation (Elson et al. 1995; Matsuura et al. 1993).

$\mathrm{CD}$ and UC are characterized by periods of remission followed by episodes of clinical relapse, characterized by an increase in symptoms usually due to acute intestinal inflammation. Treatment is primarily aimed at reducing inflammation during relapse and secondarily at prolonging the time-spent remission. Conventionally both of these aims are governed by consideration of clinical symptoms rather than objective evidence of inflammatory activity. Gastroenterologists are often faced with the difficulty of differentiating patients with irritable bowel syndrome from those with organic intestinal 
pathologies, in particular inflammatory bowel disease. Many symptoms are common to both conditions including abdominal pain, bloating, excessive flatus and altered bowel habit while other clinical features such as a predominance of diarrhea and rectal bleeding will increase the likelihood of organic disease. Although symptoms are a surprisingly good guide to a diagnosis, most clinicians proceed to and rely on laboratory tests to aid in the differential diagnosis. The two main forms of IBD are both characterized by an aberrant immune response of intestinal mucosa. The enormous complexity of pathophysiology mandates a systematic approach to identify the molecular events that cause and perpetuate these chronic, relapsing inflammatory disorders. The ability to quantitate the global expression profiles at the level of RNA using oligonucleotide microarrays has recently been applied to investigate transcriptional signatures present in CD peripheral blood and CD gastrointestinal tissue (Lawrance et al. 2001; Warner \& Dieckgraefe 2002). These studies identified genes involved in inflammatory response generally up-regulated in IBD and showed that the gastrointestinal tissue transcriptome obtained from UC and CD patients were quite distinct, with gene sets identified that appear to distinguish UC from CD tissue. In contrast to biopsies, peripheral blood is a much more accessible tissue source to distinguish between UC and CD. Circulating peripheral blood mononuclear cells (PBMCs) are responsible for the comprehensive surveillance of the body for signs of infection and disease. PBMCs may therefore serve as a surrogate tissue for evaluation of disease induced gene expression as biomarker of disease status or severity (Rockett et al. 2004).

\begin{tabular}{|c|c|c|c|}
\hline CD patient PBMC & & Age & Gender \\
\hline \multicolumn{2}{|c|}{ CD1 } & 51 & $\mathrm{~F}$ \\
\hline \multicolumn{2}{|c|}{ CD2 } & 50 & $\mathrm{~F}$ \\
\hline CD3 & & & $\mathrm{M}$ \\
\hline \multicolumn{2}{|c|}{ CD4 } & & $\mathrm{F}$ \\
\hline Control PBMC & Age & & Gender \\
\hline C1 & & & $\mathrm{F}$ \\
\hline $\mathrm{C} 2$ & 44 & & $\mathrm{M}$ \\
\hline $\mathrm{C} 3$ & & & $\mathrm{M}$ \\
\hline C4 & & & F \\
\hline C5 & \multicolumn{2}{|c|}{30} & $\mathrm{M}$ \\
\hline Biopsies & Physiological state & Age of donor & Gender of donor \\
\hline CD5 & Inflamed & 23 & $\mathrm{~F}$ \\
\hline CD6ni & Non inflamed & 24 & $\mathrm{~F}$ \\
\hline CD6i & Inflamed & 24 & $\mathrm{~F}$ \\
\hline CD7 & Inflamed & 21 & $\mathrm{~F}$ \\
\hline CD8 & Inflamed & 31 & F \\
\hline UC1 & Inflamed & 45 & $\mathrm{~F}$ \\
\hline UC2ni & Non inflamed & 20 & $\mathrm{~F}$ \\
\hline $\mathrm{UC} 2 \mathrm{i}$ & Inflamed & 20 & $\mathrm{~F}$ \\
\hline IBS 1 & Inflamed & 28 & $\mathrm{M}$ \\
\hline IBS 2 & Inflamed & 59 & F \\
\hline C6 & Non inflamed & 55 & $\mathrm{M}$ \\
\hline
\end{tabular}

Table 1. Origin of PBMCs and biopsies. $\mathrm{CD}=$ Crohn's Disease patient; UC = Ulcerative colitis patient; IBS = Irritable Bowel Syndrome patient, $\mathrm{C}=$ Disease free individual. 
We here explored expression profiles of PBMCs from four CD patients compared to age and gender matched healthy individuals. We monitored as well the expression profiles of biopsies obtained by endoscopy from five CD patients, three UC, two intestinal disorders functional and one disease free individual (Table 1). To study the transcriptome we used "Taqman Low Density Arrays" microfluidic cards (Applied Biosystems), based on the technology of real-time PCR and Taqman probes. Such strategy is particularly attractive due to the quality of measurements of gene expression, the simplicity of implementation and the 384 wells format thus covering the whole family of G Protein-Coupled Receptor (GPCR) on one plate. In this project, we used cards dedicated to study the GPCR transcriptome and this in two configurations. Card \#1 was designed in 2004 by professor J. Haiech (UMR 7200 CNRS, Faculty of Pharmacy, Illkirch). This card contained 355 GPCR, 16 housekeeping genes and 10 genes belonging to various categories. Card \#2, used for monitoring biopsies, is produced as it by Applied Biosystems (ref. 4365295). This second card, designed two years later, takes in account updates on GPCR's annotation; it contained 365 GPCR including 4 olfactory GPCR, 14 housekeeping genes and 2 genes of various functions. These two cards have 352 genes in common, including 10 housekeeping genes with 30 genes specific to each card.

\section{Materials and methods}

\subsection{Blood and tissues culture}

Healthy donors with no clinical history were selected for PBMCs and tissues studies. Patients blood and tissues were obtained from CD patients at the Gastroentetology units from Strasbourg and Caen Universities hospitals (France). This work was approved by an authorized ethics committee (CPP Nord Ouest 2, Amiens, France), and carried out according to international guidelines. A fragment of each tissue specimen (colon, ileum, small intestine) was used for histopathological studies. The other part was immediately frozen on solution D (Chomczynski and Sacchi 1987) and stored at $-70^{\circ} \mathrm{C}$. PBMCs from healthy donors were separated as previously described (Boyum 1968).

Peripheral blood diluted in $\mathrm{Ca}^{2+}$ and $\mathrm{Mg}^{2+}$ free HBSS (CMF-HBSS) containing $100 \mathrm{IU}$ heparin/ml was layered over Histopaque-1077 and centrifuged for $30 \mathrm{~min}$ at $400 \mathrm{~g}\left(20^{\circ} \mathrm{C}\right)$. Cells harvested at the interface were washed 3 times in CMF-HBSS and resuspended at a final concentration of $5 \times 10^{5}$ cells $/ \mathrm{ml}$ in RPMI 1640 supplemented by $10 \%$ heat-inactivated fetal bovin serum (FBS). PBMCs were seeded on 24-well culture plates at a final concentration of $5.10^{5}$ cells $/ \mathrm{ml}$ in RPMI-1640 supplemented with $10 \%$ heat-inactivated FBS (v/v) and penicillin-streptomycin $(100 \mu \mathrm{g} / \mathrm{ml})$. Control cells and CD patients cells were activated, or not, by LPS $(5 \mu \mathrm{g} / \mathrm{ml})$ for 2 hours $30 \mathrm{~min}$ at $37^{\circ} \mathrm{C}$. PBMCs were centrifuged and the pellets were pooled, frozen in liquid nitrogen and kept at $-80^{\circ} \mathrm{C}$ until testing.

\subsection{Flow cytometry}

Flow cytometry was performed on a Guava EasyCyte Plus System (Merck/Millipore/ Guava, Hayward, USA) equipped with a $488 \mathrm{~nm}$ laser that illuminates each cell then fluorescence is collected at different wavelength $(530 \pm 15 \mathrm{~nm}, 575 \pm 13 \mathrm{~nm}$ and $660 \pm 10 \mathrm{~nm})$. The granularity, size, cell number $/ \mathrm{ml}$ and fluorescence are recorded at a speed of 800 cells per second. 


\subsection{TNF- $\alpha$ secretion tests}

Human PBMCs were incubated in 24 well culture plates in culture medium at $5 \times 10^{5} \mathrm{cells} / \mathrm{ml}$ for $24 \mathrm{~h}$ at $37^{\circ} \mathrm{C}$ in a humidified $5 \% \mathrm{CO}_{2} / 95 \%$ air atmosphere in presence of increasing concentrations of the somatostatin analogues ranging from $10^{-7} \mathrm{M}$ to $10^{-5} \mathrm{M}$, with or without activation by LPS $(5 \mu \mathrm{g} / \mathrm{ml})$. Compounds were dissolved in water. Control samples always contained the same amount of water (without compounds). For ELISA, plates were centrifuged after incubation for $15 \mathrm{~min}$ at $200 \mathrm{xg}\left(20^{\circ} \mathrm{C}\right)$. Supernatants were stored at $-80^{\circ} \mathrm{C}$ until testing. For coating, human TNF- $\alpha$ antibody $0,5 \mathrm{mg} / \mathrm{ml}$ (BD Pharmingen, Le Pont de Claix, France) was diluted to $1 / 100$ in Binding Solution $\left(\mathrm{Na}_{2} \mathrm{HPO}_{4} 0,1 \mathrm{M}+\mathrm{NaH}_{2} \mathrm{PO}_{4} 0,1 \mathrm{M}\right.$ à pH9) and added in the 96 wells plate (Nunc Maxisorp 96-wells, VWR, Val de Fontenay, France). The plate was sealed to prevent evaporation, and incubated overnight at $4^{\circ} \mathrm{C}$. The 96-wells plate was then washed once with PBS $1 x$ /Tween 0,05\% then saturated by addition of $200 \mu \mathrm{l} \mathrm{PBS} / \mathrm{milk} 5 \%$ during 2 hours at room temperature. After two washes with PBS $1 \mathrm{x} /$ Tween $0,05 \%$, PBMC supernatants were added. TNF- $\alpha$ protein standard $1 \mu \mathrm{g} / \mathrm{ml}$ (BD Pharmingen, Le Pont de Claix, France) with dilutions (10000, 3333, 1111, 370, 123, 41 and $5 \mathrm{pg} / \mathrm{ml}$ ) was added in corresponding standard wells for the statistic correlation. The detection was done with Human TNF- $\alpha$ biotin $0,5 \mathrm{mg} / \mathrm{ml}$ (BD Pharmingen, Le Pont de Claix, France) during one hour at room temperature. The plate was washed four times with PBS 1x/Tween 0,05\%. Peroxydase/streptavidin 1,25 mg/ml (Zymed, In Vitrogen, Cergy Pontoise, France) was added and the plate incubated for one hour at room temperature. The plate was washed four times in PBS 1x/Tween 0,05\%, and OPD (Sigma, Lyon, France) was used to determine the amount of TNF- $\alpha$ detected in each well. The plate was then analysed in a spectrophotometer at 450nm (Molecular Devices, VersaMax Tunable Microplate Reader, Sunnyvale, USA).

\subsection{RNA Extraction of tissues and PBMCs}

The tissues were defrosted 15 minutes on ice (Chomczynski \& Sacchi 1987). The cells were broken with a sterile piston, and put in sodium acetate $2 \mathrm{M} \mathrm{pH} 4$, phenol $\mathrm{pH} 4$ saturated and chloriform/isoamylic alcool (49:1). After shaking, the membranes were incubated 15 minutes on ice and centrifuged 20 minutes at $12000 \mathrm{~g}$ at $4^{\circ} \mathrm{C}$. Aqueous phase with the RNA were kept and precipitated with isopropanol one hour at $-20^{\circ} \mathrm{C}$. The RNA were centrifuged 20 minutes $12000 \mathrm{~g}$ at $4^{\circ} \mathrm{C}$, and washed with $500 \mu \mathrm{l}$ of ethanol $70 \%$ stored at $-20^{\circ} \mathrm{C}$. They were centrifuged 5 minutes $12000 \mathrm{~g}$ at $4^{\circ} \mathrm{C}$ and washed again three times. The RNA were dried with Speed Vac, and added with sterile water. RNA was isolated from PBMC cells pellet (5.106 cells) with Tri reagent (Molecular Research Center, Inc., Cincinnati, Ohio, USA) according to the manufacturer's instructions.

Total mRNA were checked for integrity and concentration using the RNA 6000 LabChip kit on the Agilent 2100 bio analyzer (ratios of 28S RNA/18S RNA were above 1.6) and for purity by reading the absorbance at 260 and $280 \mathrm{~nm}$ (ratios A260/A280 were comprised between 1.8 and 2.0 ).

\subsection{Real-Time RT-PCR and PCR}

Five $\mu \mathrm{g}$ of total RNA is reversely transcribed to single-stranded cDNA using the "HighCapacity cDNA AUCive ${ }^{\mathrm{TM}} \mathrm{Kit}^{\prime \prime}$ (Applied Biosystems, Foster City, California, USA). RNA is pre-incubated at $25^{\circ} \mathrm{C}$ for $10 \mathrm{~min}$, followed by 2 hours at $37^{\circ} \mathrm{C}$, according to the manufacturer's recommendations (Applied Biosystems, Foster City, California, USA). 
Subsequently, cDNA was kept at $-20^{\circ} \mathrm{C}$ until used. An aliquot of cDNA (850 ng) was mixed carefully in $850 \mu \mathrm{L}$ TaqMan Universal PCR Master Mix (PE Applied Biosystems). On the card keeped at room temperature, $105 \mu \mathrm{L}$ of the sample were loaded into each of 8 ports on the TaqMan Low-Density Array (Applied Biosystems, Foster City, CA). The TaqMan LowDensity Array microfluidic card \#1 consists of a preconfigured in a 384-well format to assess the expression of 355 GPCR genes. The card \#2 has 365 GPCR genes as well as 4 olfactives GPCR. The cards were then centrifuged twice in custom Buckets (Applied Biosystems, CA USA) in a Heraeus centrifuge (Kendro Scientific, Asheville, NC, USA) for $1 \mathrm{~min}$ at $1200 \mathrm{rpm}$. The cards were immediately sealed with the TaqMan Low-Density Array Sealer (Applied Biosystems, CA USA) to prevent any cross-contamination. Real-time RT-PCR is then performed on an ABI Prism 7900 (Applied Biosystems, Foster City, CA). Thermal cycling, to activate uracil-DNA glycosylase, is carried out for $2 \mathrm{~min}$ at $50^{\circ} \mathrm{C}, 10 \mathrm{~min}$ at $94.5^{\circ} \mathrm{C}$ then 40 cycles of $30 \mathrm{~s}$ at $97^{\circ} \mathrm{C}$ and $60 \mathrm{~s}$ at $59.7^{\circ} \mathrm{C}$. Each reaction contained cDNA derived from around $1.5 \mathrm{ng}$ of total RNA.

\subsection{Statistics}

Real-time RT-PCR data were quantified using the SDS 2.2.1 software package (Applied Biosystems). Results were quantified in a relative comparative study, using an automatic baseline and threshold to record the cycle thresholds (Cts) setting and the 18S rRNA gene expression as a reference for normalization $(\Delta \mathrm{Cts})$. Student's $t$-test was used with a significance threshold of $\mathrm{P}<0.05$. ELISA data are expressed as a percentage of the basal cytokine secretion level or as means $( \pm \mathrm{SE})$; ' $\mathrm{n}$ ' refers to the number of experiments. Results were compared using the non-parametric Mann-Whitney U test. The level of statistical significance was fixed at $\mathrm{P}<0.05$.

\section{Results}

By monitoring non-orphan RCPGs (i.e. 279 among the 382 RCPGs tested) in PBMCs of 10 healthy donors and $10 \mathrm{CD}$ patients we found that the data obtained were highly dependent on RNA integrity. The integrity of RNA molecules is of paramount importance for experiments that try to reflect the snapshot of gene expression at the moment of RNA extraction. The RNA integrity number (RIN) is an important tool regrettably often disregarded, in conducting valid gene expression measurement experiments as real-time PCR or DNA microarray (Schroeder et al. 2006). After RIN determination of our 20 samples, only $4 \mathrm{CD}$ patients and 4 paired healthy donors could be considered reliable due to sample degradation yet with handling and shipping in dry ice from the hospital to the laboratory.

\subsection{Standardization}

Figure 1 represented a Dot Blot reflecting dispersion of 10 Housekeeping genes (PBMCs and biopsies). Before standardization, values $(\mathrm{Ct})$ of 10 genes presented a distribution around $50 \%$ of the median of the samples. However gene GUSB had weaker variance and symmetrical distribution compared to median. The distribution of ARNr $18 \mathrm{~S}$ values is relatively good compared to whole of other Housekeeping genes excepting two samples presenting extreme values. The literature relates that genes of the sugar metabolism were found deregulated in biopsies of IBD patients (Dieckgraefe et al. 2000) this fact encouraged us to choose 18S RNA to standardize our samples. After standardization, genes generally 


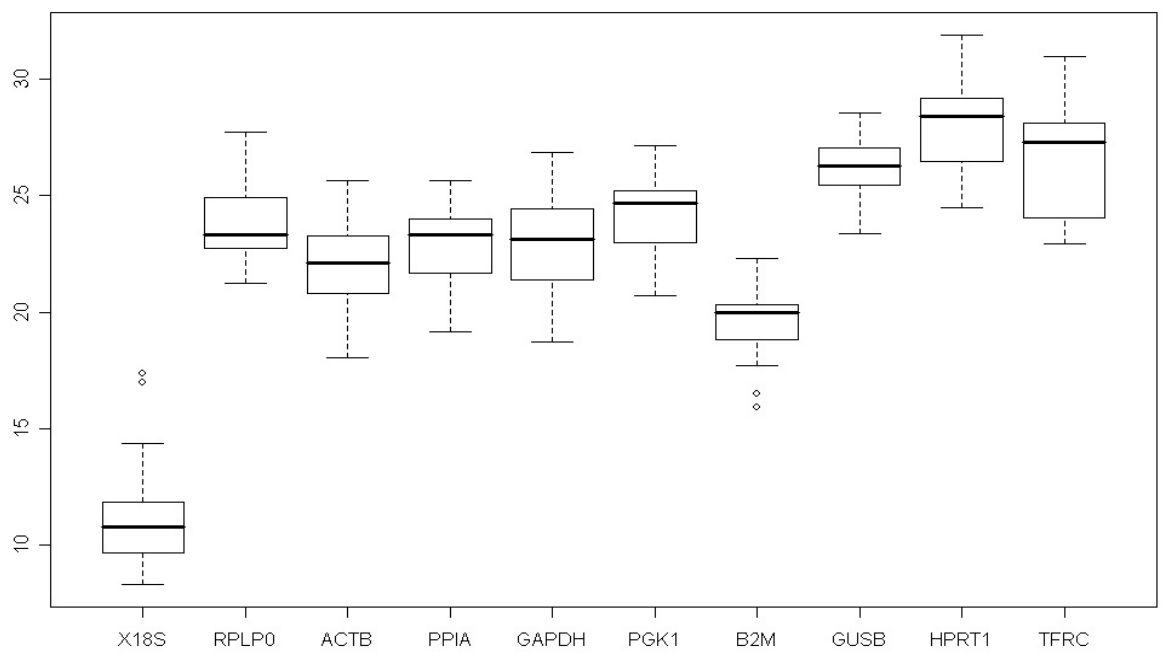

(A)

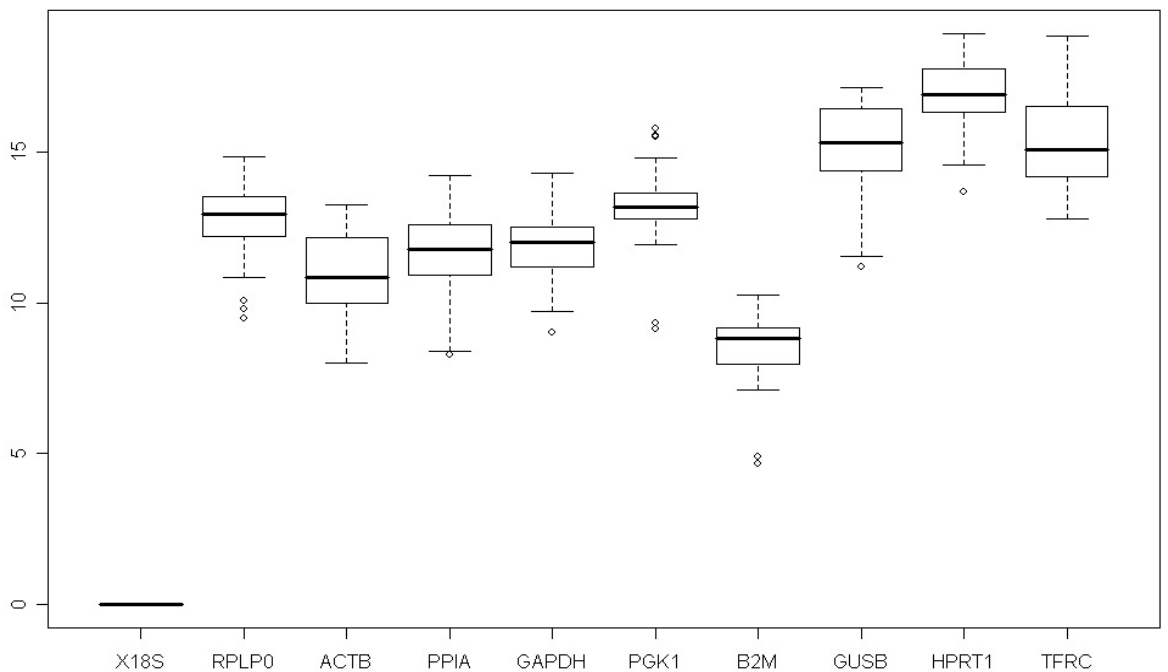

(B)

Fig. 1. Dot blot of 10 Housekeeping genes before (A) and after (B) standardization to $18 \mathrm{~S}$ RNA.

showed a weaker dispersion, but we noticed that several genes like PGK1, RPLP0 and B2M presented extreme values. The fact that 3 genes out of 10 Housekeeping genes are not standardized the same manner, states clearly that genes are connected to different ways of metabolism which ways are affected by cell deregulation. For example, many reports on ratios show that the level of GAPDH messenger does not remain constant. Even if the GAPDH gene was considered for years as a reference in genetic organization, expression 
and regulation studies, recent evidences demonstrate that mammalian GAPDH displays a number of diverse activities unrelated to its glycolytic function. For example, GAPDH messenger variations of enzymatic activity are implied in many mechanisms as varied as replication of DNA, transport of nuclear ARN and organization of cytoskeletal (Sirover 1999) as well as neurodegenerative diseases.(Tatton et al. 2000)

\subsection{Gene clustering}

Before seeking genes differentially expressed in statistical systems with two classes, we wanted to know if it is possible to group samples in classes that characterize them with profile genes and type of pathology of patient to differentiate CD and UC. We followed a supervised approach which data groups without existing classes. Procedure of clustering consists in classifying a whole of data in several subsets according to their similarities. Data of expression form a matrix whose lines correspond to genes, here genes common to both cards, and columns with 17 samples. First, data were filtered so general average of form of genes is lower than $38 \mathrm{Ct}$, then standardized compared to ARNr $18 \mathrm{~S}$.

The tree diagram or dendrogram illustrates the arrangement of clusters produced by hierarchical clustering. The individuals who resemble the most to each other are gathered in the bottom of the tree. The length of the branches is proportional to their distance among each other. The matrix of expression data is coloured coded according to the relative level of gene expression of genes: colours go from green for level of high expression to red for level of low expression, with black for intermediate level (units expressed in $\Delta \mathrm{Ct}$ ).

Figure 2 shows an ascending hierarchical classification by using Pearson's coefficient of correlation to measure the distance between two points. This distance reflects proximity or similarity between two points. Using Euclidean distance, which measures dissimilarity between two points and is more sensitive to amplitude of variations between data, produces regrouping of the data as illustrated into Figure 3.

The data regrouping are obtained in form of two dendrograms, for genes and for individuals for each card. Classification distributes samples in 2 principals groups, PBMCs and biopsies. This first scission marks differences related nature of tissues. Then within each one of these 2 regroupings, we distinguish sub-groups:

- $\quad$ for the PBMC group: the subgroup of healthy individuals differs markedly from that of patients with $C D$, each of these subgroups appear marginally affected by treatment with LPS.

- for the biopsy group: the formation of sub-groups is less obvious, as is the interpenetration of these sub-groups: healthy subjects, healthy areas of patients with $\mathrm{CD}$, healthy areas of patients with UC and inflammatory areas in patients with $C D$, inflammatory areas in patients with UC, and finally mucosa of patients with IBS. This behavior is certainly due to an insufficient number of samples representing each class, including healthy people and healthy areas of patients. These ambiguous groupings of biopsies outside their own classes indicate a high level of variation in gene expression in samples.

In addition, dispersion curves (fig. 4 and 5) illustrate the heterogeneity of genes form in samples supposed to represent the same IBS. The correlation curves expression data of biopsies from inflammatory areas of patients with UC show a large dispersion of values in contrast to results obtained with patients CD. Indeed, the correlation coefficient of patients with UC or IBS is much lower (near 0.6) than that obtained with the data on three areas of biopsies from patients with inflammatory CD (around 0.8) 


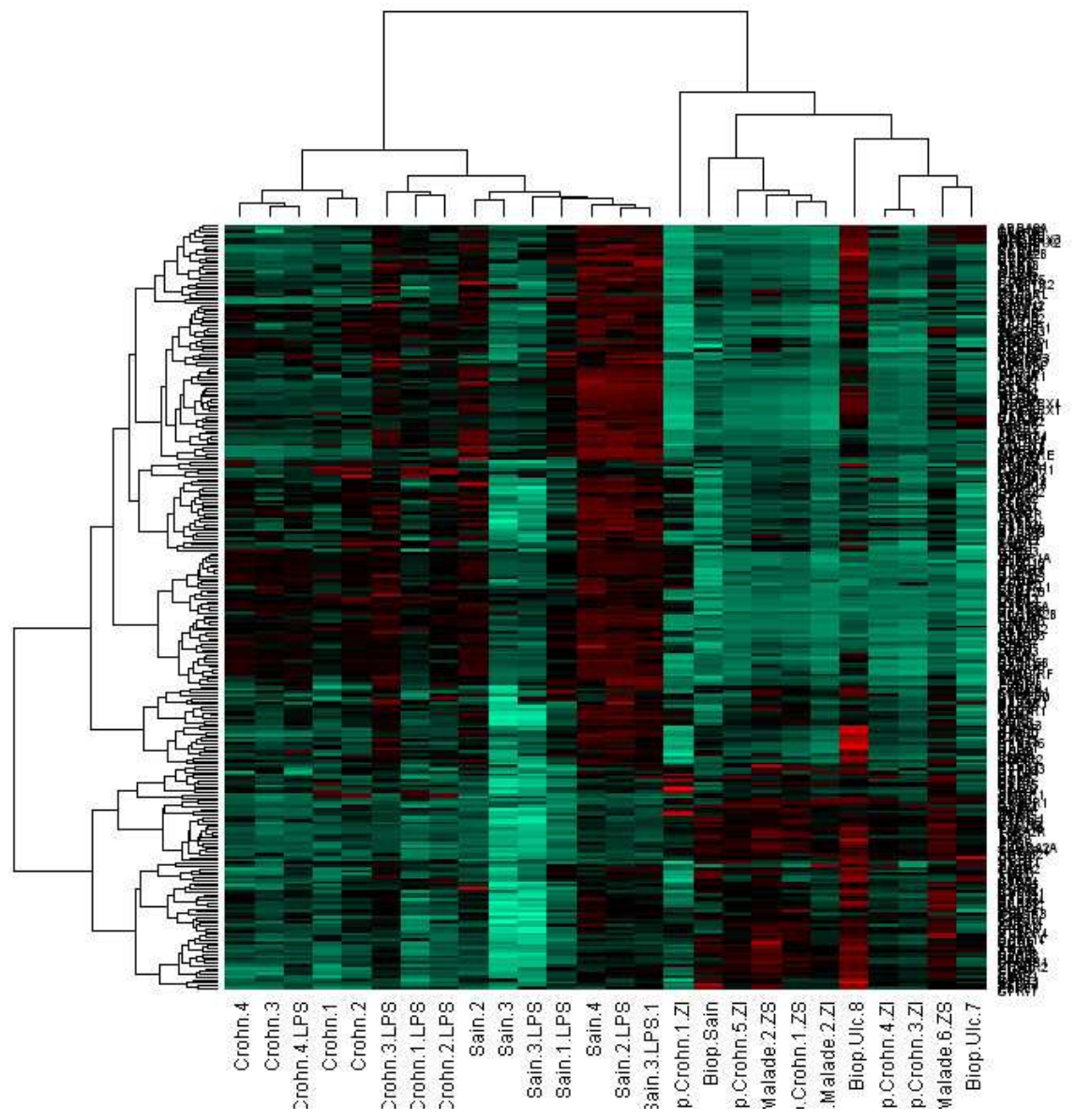

Fig. 2. GPCRs expression profile by ascending hierarchical classification of the samples. 


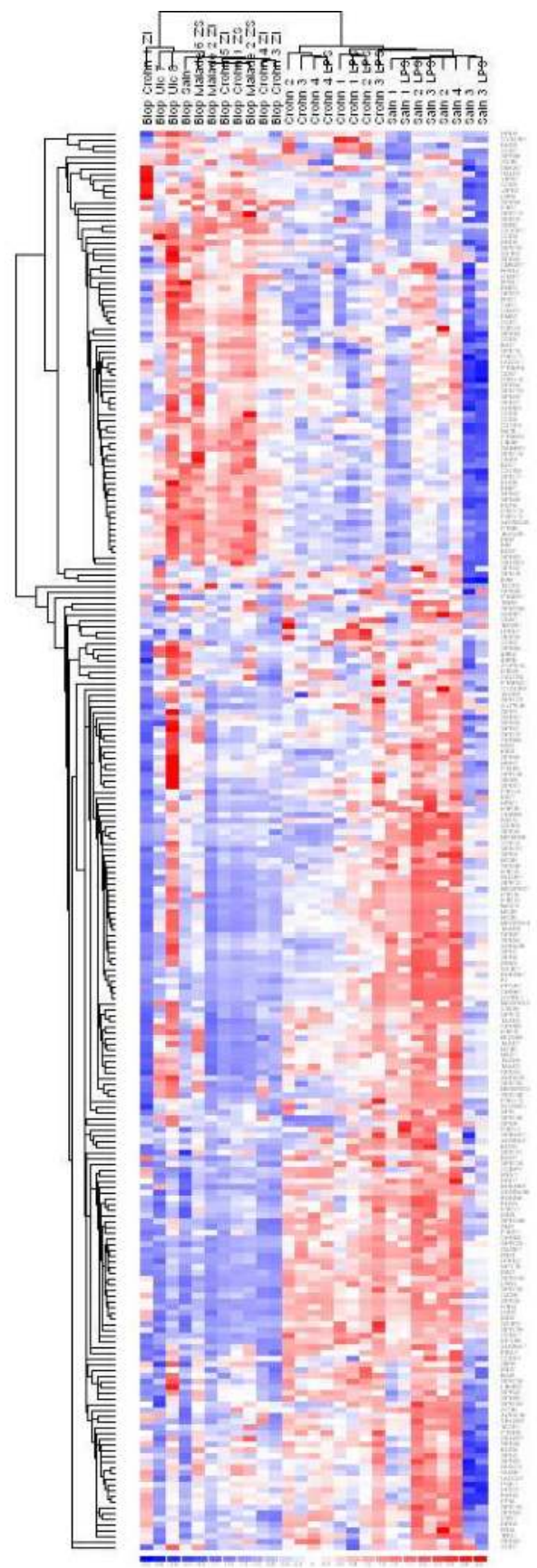

Fig. 3. Ascending hierarchical classification using Euclidean distance to measure dissimilarity and average enters groups for algorithm of aggregation. 


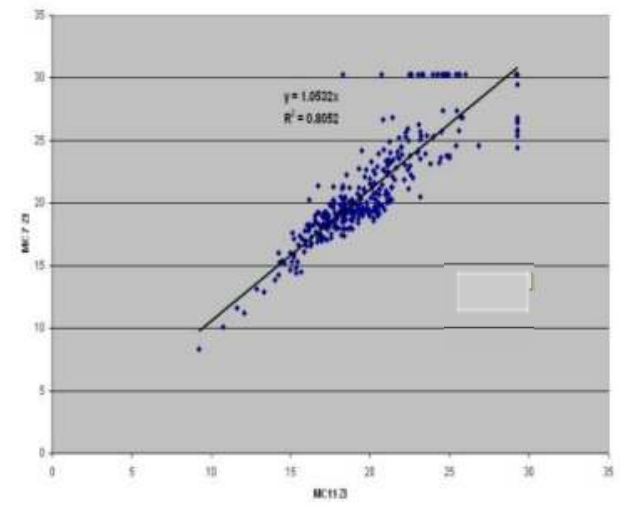

(A)

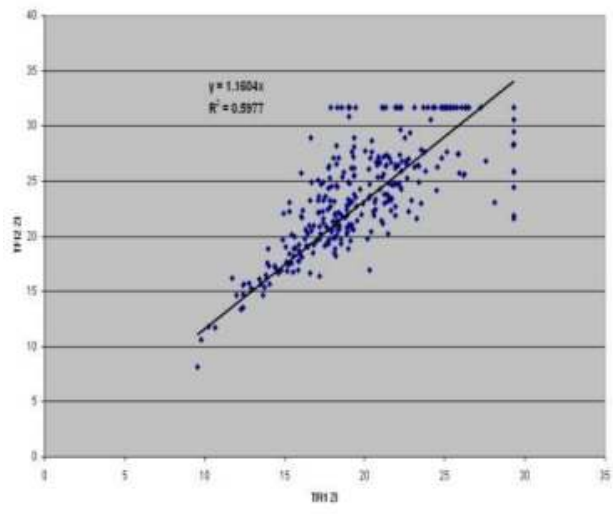

(B)

Fig. 4. Gene dispersion curves for CD (A) and IBS (B) biopsies.

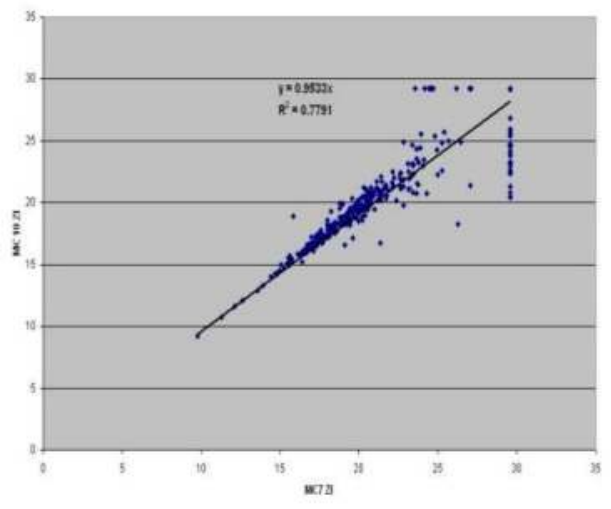

(A)

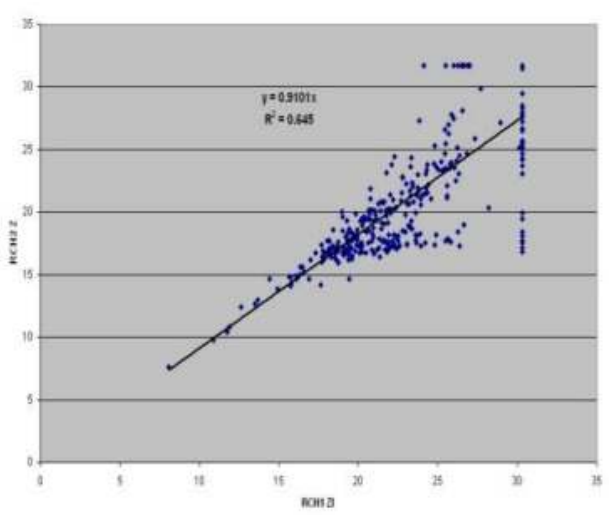

(B)

Fig. 5. Gene dispersion curves for CD (A) and UC (B) biopsies.

The origins of these dispersions are many. First, in a technical point of view, the collection is a delicate operation to achieve in the bowel (colonoscopy) and the removal of the tissue requires expertise to pick the exact target area by damaging the minimum completeness of tissue removed. On the other hand, in a biological point of view, the heterogeneity of individuals (age, sex, treatment, diet, etc..) And the exact position where the taking is in the intestinal tract, are major sources of heterogeneity. The difficulty of our work was to remove background noise genes specifically associated with CD. In addition, changes in profiles of biopsies may represent different levels of evolution and development of the disease. Indeed, there may be a great variability of samples supposed to represent a single disease state or biological replicas considered in the statistical analysis. To achieve this level of interpretation, the data should be obtained on a large number of individuals in a population well characterized.

This grouping study provides assurance that the GPCR expression profiles in PBMCs can distinguish $\mathrm{CD}$ from healthy subjects. It shows, however, the existence of heterogeneity of 
expression profiles of GPCR and a large variance in the expression of genes in the biopsies, this should not be overlooked when analysing the data.

\subsection{Normal distribution of data}

Parametric statistical tests on the means involve the estimation of parameters such as variance. These tests are generally more powerful than nonparametric tests, but require as a condition for applying the normality of data distribution of the mean. Although the tests called parametric tests are quite robust, i.e. are insensitive to a deviation from normality (as long as you estimate the variance) and are often used as the mode of data distribution deviates slightly of normality, it is useful to test the normality of data distribution.

We used the correlation test of Ryan-Joiner, similar to the Shapiro-Wilk test, as proposed in the Minitab software. The test generates a line of Henry and performs a hypothesis test to see if the observations are normally distributed. The assumptions of the test are: $\mathrm{H} 0$, the data follow a normal distribution against $\mathrm{H} 1$, the data do not follow a normal distribution. Using this test, we submitted the data from 9 housekeeping genes (Table 2) thru the 27 samples for the goodness of fit to a Gaussian distribution.

\begin{tabular}{|c|c|c|c|c|}
\hline $\begin{array}{c}\text { Gene } \\
\text { symbol }\end{array}$ & Assai ID & Gene Name & $\begin{array}{c}\text { NCBI gene } \\
\text { reference }\end{array}$ & $\begin{array}{c}\text { Chromo- } \\
\text { some }\end{array}$ \\
\hline RPLP0 & Hs99999902_m1 & Ribosomal protein, large, P0 & NM_053275 & 12 \\
\hline PPIA & Hs99999904_m1 & Peptidylprolyl isomerase A (cyclophilin A) & NM_203430 & 7 \\
\hline GAPD & Hs99999905_m1 & Glyceraldehyde-3-phosphate dehydrogenase & NM_002046 & 12 \\
\hline HIST1H1C & Hs00271185_s1 & Histone 1, H1c & NM_005319 & 6 \\
\hline HPRT1 & Hs99999909_m1 & Hypoxanthine phosphoribosyltransferase 1 & NM_000194 & X \\
\hline HSPCA & Hs00743767_sH & Heat shock 90kDa protein, 1 alpha & NM_005348 & 14 \\
\hline PGK1 & Hs99999906_m1 & Phosphoglycerate kinase 1 & NM_000291 & X \\
\hline K-ALPHA-1 & Hs00744842_sH & Tubulin, alpha, ubiquitous & NM_006082 & 12 \\
\hline RARS & Hs00259879_m1 & Arginyl-tRNA synthetase & NM_002887 & 5 \\
\hline ACTB & Hs99999903_m1 & Actin, beta & NM_001101 & 7 \\
\hline B2M & Hs99999907_m1 & Beta-2-microglobulin & NM_004048 & 15 \\
\hline CYC1 & Hs00357717_m1 & Cytochrome c-1 & NM_001916 & 8 \\
\hline GUSB & Hs99999908_m1 & Glucuronidase, beta & NM_000181 & 7 \\
\hline TFRC & Hs99999911_m1 & Transferrin receptor (p90,CD71) & NM_003234 & 3 \\
\hline NUP62 & Hs00383013_m1 & Nucleoporin 62kDa & NM_153719 & 19 \\
\hline 18S & & Ribosomal RNA 18S & & \\
\hline
\end{tabular}

Table 2. Housekeeping list presents in the Applied Biosytem microfluidic card.

Of the nine genes tested, 7 of them verify the hypothesis H0, the data follow the normal distribution, the risk of first type $\alpha$ of 0.01 (Figure 6). Only two genes, PGK1 and B2M have $p$ values less than 0.01 . These results can be linked with the dispersal rate of expression of these genes, as was noted earlier. The test results are for a normal distribution of data and give us confidence in using the Student test. 

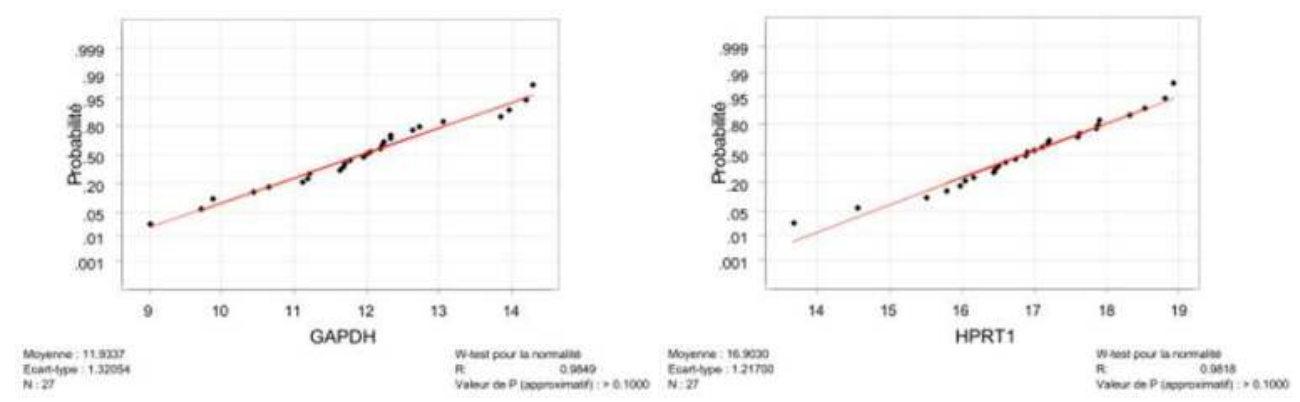

Fig. 6. Test of normality by the Ryan-Joiner test of correlation. The vertical axis represents scale of probabilities and horizontal axis scale of data. A line of least squares is adjusted at raised points and is traced on graph for reference. The line represents an estimate of function of pattern of settlement from where data are extracted. The estimates of parameters average and standard deviations of population are posted under graph.

\subsection{Gene expression in PBMCs of CD patients versus control}

It is now widely accepted that GPCRs, including cytokine receptors play a critical role in controlling the inflammatory response (Luther \& Cyster 2001; Onuffer \& Horuk 2002; Thelen 2001). It has been shown that immune cells express many receptors of neuropeptides and neurotransmitters, highlighting the role of mediators in the neuroendocrine modulation of immune response. In addition, there is a bundle of evidence indicating the existence of relationship between GPCR signaling pathways and answers related to antigen receptor of $T$ cells and interleukin-2. Thus, prostaglandins produced by activated macrophages during the immune response can inhibit both cytokine production and proliferation of $\mathrm{T}$ cells (Baker et al. 1981). These observations motivated us to work with PBMCs, a more homogeneous cell population much less restrictive than the colon biopsies of patients. In our study on PBMCs taken from four healthy subjects and four patients with CD in remission, the expression profiles of GPCRs were obtained on card \#1.

The genes were previously filtered to eliminate those not expressed in any of the samples, so that they are about 85 genes remaining. The were two reason of this operation: i) reduce variance brought by genes not expressed during calculation of $\Delta \mathrm{Ct}$ since these genes have $\mathrm{Ct}$ equal to 40; ii) avoid null denominators in calculations in particular standard deviations. This does not mean that all 296 selected genes are expressed. Values are normalized to 18S rRNA in each sample. The differentially expressed genes between the normal subjects and CD patients were obtained from the p-value of the Student test at risk of type $\alpha$ equal to 0.05 . The difference in expression between the two classes of individuals was determined from the difference between the average $\Delta \mathrm{Ct}$ healthy subjects and the average $\Delta \mathrm{Ct}$ of $\mathrm{CD}$ patients.

$$
\Delta \Delta \mathrm{Ct}=\left(\Delta \mathrm{Ct}_{\text {healthy }}-\Delta \mathrm{Ct}_{\mathrm{CD}}\right)
$$

The data of the 22 differentially expressed genes were subjected to a nonparametric test, more robust and less sensitive to extreme values. The Mann-Whitney test for unpaired data with Minitab software calculates the value $\mathrm{p}$ and focuses on the equality of medians of two groups. Figure 7 shows two examples of the report of the results for Minitab for gene SSTR5 and $A D R A 2 B$ for a threshold of the first kind $\alpha$ of 0.05 . The data of the first gene name can reject the hypothesis $\mathrm{H} 0$ while those of $A D R A 2 B$ does not allow it. 
Inflammatory Bowel Disease G-Protein Coupled

Receptors (GPCRs) Expression Profiling with Microfluidic Cards

\begin{tabular}{|c|c|c|c|c|c|c|}
\hline Assay ID & $\begin{array}{c}\text { Gene } \\
\text { Symbol }\end{array}$ & Gene Name & T-TEST & $\Delta \Delta \mathrm{Ct}$ & $\begin{array}{l}\text { Standard } \\
\text { Deviation }\end{array}$ & $\begin{array}{c}\text { Mann-Whitney } \\
\text { test }\end{array}$ \\
\hline Hs00664150_s1 & $M R G P R E$ & $\begin{array}{l}\text { MAS-related GPR, } \\
\text { member E }\end{array}$ & 0.007 & 9.8 & 2.10 & Rejection \\
\hline Hs00265647_s1 & SSTR5 & somatostatin receptor 5 & 0.038 & 9.6 & 2.50 & Rejection \\
\hline Hs00664166_s1 & GPR142 & $\begin{array}{l}\text { G protein-coupled } \\
\text { receptor } 142\end{array}$ & 0.011 & 9.5 & 2.22 & Rejection \\
\hline Hs00270999_s1 & GPR4 & $\begin{array}{l}\text { G protein-coupled } \\
\text { receptor } 4\end{array}$ & 0.018 & 8.4 & 2.15 & Rejection \\
\hline Hs00266671_s1 & $F Y$ & Duffy blood group & 0.020 & 7.8 & 2.26 & Rejection \\
\hline Hs00265617_s1 & SSTR1 & somatostatin receptor 1 & 0.024 & 7.8 & 2.10 & Rejection \\
\hline Hs00664089_s1 & GPR148 & $\begin{array}{l}\text { G protein-coupled } \\
\text { receptor } 148\end{array}$ & 0.023 & 7.6 & 2.19 & Rejection \\
\hline Hs00275980_s1 & PPYR1 & $\begin{array}{c}\text { pancreatic polypeptide } \\
\text { receptor } 1\end{array}$ & 0.022 & 7.3 & 2.39 & Rejection \\
\hline Hs00271049_s1 & GPR20 & $\begin{array}{l}\text { G protein-coupled } \\
\text { receptor } 20\end{array}$ & 0.017 & 7.2 & 2.35 & Rejection \\
\hline Hs00265195_s1 & CHRM1 & $\begin{array}{c}\text { cholinergic receptor, } \\
\text { muscarinic } 1\end{array}$ & 0.035 & 6.7 & 2.15 & Rejection \\
\hline Hs00271017_s1 & GPR7 & $\begin{array}{l}\text { G protein-coupled } \\
\text { receptor } 7\end{array}$ & 0.030 & 6.3 & 2.16 & Rejection \\
\hline Hs00271023_s1 & GPR8 & $\begin{array}{l}\text { G protein-coupled } \\
\text { receptor } 8\end{array}$ & 0.002 & 6.1 & 1.52 & No rejection \\
\hline Hs00664201_s1 & $B D K R B 1$ & bradykinin receptor B1 & 0.049 & 5.8 & 2.19 & No rejection \\
\hline Hs00271008_s1 & GPR6 & $\begin{array}{l}\text { G protein-coupled } \\
\text { receptor } 6\end{array}$ & 0.044 & 5.5 & 2.03 & No rejection \\
\hline Hs00706455_s1 & CCR10 & $\begin{array}{c}\text { chemokine (C-C motif) } \\
\text { receptor } 10\end{array}$ & 0.015 & 5.3 & 2.02 & No rejection \\
\hline Hs00268954_s1 & FZD9 & $\begin{array}{l}\text { frizzled homolog } 9 \\
\text { (Drosophila) }\end{array}$ & 0.016 & 5.3 & 1.86 & No rejection \\
\hline Hs00265090_s1 & $A D R A 2 B$ & $\begin{array}{l}\text { adrenergic, alpha-2B-, } \\
\text { receptor }\end{array}$ & 0.047 & 4.5 & 1.96 & No rejection \\
\hline Hs00265286_s1 & HTR1B & $\begin{array}{l}\text { 5-hydroxytryptamine } \\
\text { (serotonin) receptor 1B }\end{array}$ & 0.026 & 4.1 & 1.57 & No rejection \\
\hline Hs00184657_m1 & BAI2 & $\begin{array}{c}\text { brain-specific } \\
\text { angiogenesis inhibitor } 2\end{array}$ & 0.041 & -2.4 & 1.44 & No rejection \\
\hline Hs00222094_m1 & HRH4 & histamine receptor $\mathrm{H} 4$ & 0.050 & -2.5 & 1.57 & No rejection \\
\hline Hs00181231_m1 & ADORA1 & adenosine $\mathrm{A} 1$ receptor & 0.028 & -3.3 & 1.74 & No rejection \\
\hline Hs00173471_m1 & OPRL1 & opiate receptor-like 1 & 0.004 & -5.1 & 1.71 & Rejection \\
\hline
\end{tabular}

Table 3. Results of p-values for 22 genes.

The results of the p-values have been reported in Table 3: 14 of 22 genes confirmed the results of the parametric test (MRGPRE, SSTR5, GPR142, GPR4, FY, SSTR1, GPR148, PPYR1, GPR20, CHRM1, GPR7, FZD9, and HTR1B OPRL1).

The Mann-Whitney, which addresses to data from samples drawn randomly and independently in two populations of the same variance, is limited here by the low number of individuals tested. Having duplicate data, that is to say to increase the "NR" to 8 instead of 4 and keeping the same values of the medians, produces a p-value less than 0.05 . All genes in Table 3 for which the hypothesis $\mathrm{H} 0$ could be rejected for $\mathrm{NR}$ equal to 4 , are regarded significantly different by the mere fact of double samples. This is proven by a ratio of Minitab for $A D R A 2 B$ with NR equal to 8. 
Knowing that the signed rank test 2-sample is slightly less powerful than the test samples with 2 grouping of sample variance when the populations are normal, and taking into account the recommendations of Minitab software for populations with different standard deviations, we have privileged a 2-sample $t$ test without pooling the variances for the analysis of differential genes.

Of the 22 genes differentially expressed in PBMC of CD patients compared to normal subjects, 18 were overexpressed, while four are under-expressed. The overexpressed genes are mostly induced in the disease except $A D R A 2 B$ and GPR 8 receptors that are expressed in PBMCs of normal subjects. Among these genes are receptors involved in the inflammatory and immune (SSTR5, SSTR1, CHRM1, CCR10, FY, BDKRB1, HTR1B) in other processes (MRGPRE, PPYR1, FZD9) and unknown functions (7 orphan receptors: GPR4, GPR142, GPR148, GPR20, GPR7, GPR8, GPR6). In a similar approach, Burczynski ME and collaborators research in PBMC gene expression signatures to discriminate $C D$ of UC. They used the Affymetrix microarray platform HG-U133A that allows you to query more than 22000 genes with a sample of 42 normal individuals and 59 CD patients (Burczynski et al. 2006). Their data were deposited in the database of microarrays GEO "Gene Expression Omnibus" at NCBI and are available to the community in the form of CEL files. CEL files are files that contain Affymetrix raw data. The site also allows to directly visualize the expression profile of a gene selected from across all samples as a histogram. Out of the 22 genes on the TLDA microfluidic cards, 16 are present on the chip. By submitting data at the same t-test that was used at the threshold 0.05, 5 genes appear differentially expressed in CD patients compared to normal individuals (FZD9, SSTR1, CCR10, HTR1B, OPRL1) with reports of expression ranging from 1.83 (FZD9) and 0.75 (OPRL1). The very low expression of these 16 genes on the chip confirms the absence of expression observed in real-time PCR in healthy individuals (SSTR5, SSTR1, FZD9, CCR10, HTR1B, GPR6, FY, ADORA1, BDKRB1, PPYR1, GPR20, GPR4). The discrepancy concerning the magnitude of changes in expression levels (less than 2 with the microarray against values higher then 16 in real-time PCR) between the two sets of data can be related to the difference in sensitivity of two technologies, real-time PCR being much more sensitive than the oligonucleotide hybridization technique.

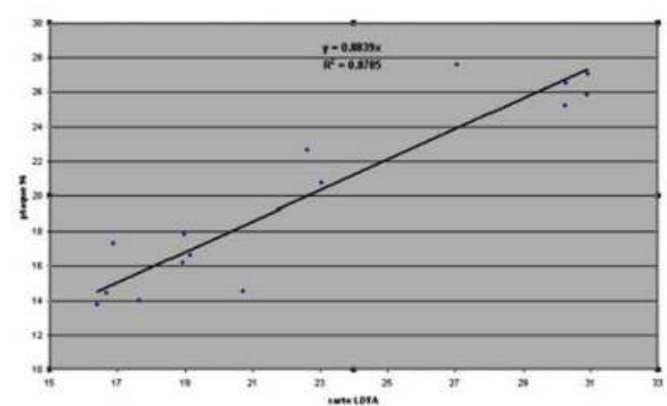

(A)

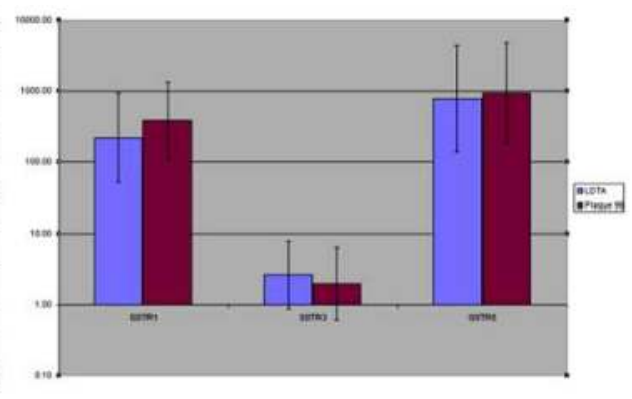

(B)

Fig. 7. Validation of results obtained by real-time PCR in 96 well plates as compared to LDTA card. (A) Correlation curve for SSTR5 data. (B) Ratio of expression rates between CD patient and disease free individuals for 3 somatostatin receptors for data obtained by using microfluidic cards or 96 plates technology.. 
The presence among this group of receptor genes in the same family, SSTR1 and SSTR5, which in addition show a strong increase of expression in CD patients, is interesting. This prompted us to conduct a new measurement of the expression of these genes by real-time PCR but using 96-well plate format. This makes it possible to assess the performance of the microfluidic card system, i.e. if the differences of expression come from technology, rheology, the depot of the tests in the cards, etc. Complementary DNA has been a resynthesized from total RNA and PCR was conducted under the same conditions of reagents on the ABI Prism 7000 thermocycler. We add to the experience another somatostatin receptor, SSTR3, whose expression is unchanged in microfluidic card TLDA. The histogram in Figure 7 confirms the results achieved with the microfluidic card and the curve (Fig.7A) shows good correlation between measurements of two technologies.

\subsection{Healthy subjects and CD patients with LPS activation}

We tested the ability of PBMC from healthy individuals and CD patients with to induce the production of TNF- $\alpha$ in response to LPS stimulation. After 24 hours incubation with LPS, we measured the release of TNF- $\alpha$. We observed a production of TNF- $\alpha$ in the two groups of people consolidating us on the effectiveness of PBMC to respond to LPS. PBMCs of CD patients produce TNF- $\alpha$ twice as much as healthy subjects (data not shown).

Concerning gene expression, the data analysis was performed using an approach similar to the one described before. However, we applied here more strict filters by removing genes whose mean $\mathrm{Ct}$ was greater than 37. In this area of values measuring variations are significant. They are due on the one hand to the lack of reproducibility of withdrawals that is related to the Gaussian distribution of the sample in a solution containing a small number of copies of cDNA, and secondly, the SDS software that assigns a Ct of 40 to genes for which the amplification curve does not reach a plateau, as they cross the threshold between the 37th and 40th cycle.

Values were first normalized to $18 \mathrm{~S}$ rRNA then for each individual, the difference of $\Delta \mathrm{Cts}$, the $\Delta \Delta$ Cts between the PBMC stimulated or not by LPS was computed. We also calculated the average values of $\Delta \Delta$ Cts obtained from four individuals. The genes whose expression is regulated by the activation of PBMC by LPS in normal subjects were selected on the one hand for an average of $\Delta \Delta$ Cts values greater than 1.5 and less than -1.5 , and to the other from the p-value of Student's test for paired data at risk of Type $\alpha$ equal to 0.05 . We obtained 18 genes (Table 4) whose expression is significantly LPS dependent, of which 4 are overexpressed and 14 repressed. With the exception of GPRC5A the three overexpressed genes (GPR155, SSTR3, H963) are well expressed in the non-activated PBMC from healthy subjects. Among these genes are many receptors known to be involved in the inflammatory process and immune response (EDG2, EMR2, EMR3, CCR1, GPR35, FPr1, CCR3, CMKLR1, C5R1, FPRL2, P2RY2, GPBAR1) with two orphan receptors (GPR77, GPR162).

The same experiment conducted with PBMC from CD patients, stimulated or not with LPS, shows a profile of genes regulated by LPS very similar to that obtained in healthy subjects, but with a more important difference between those genes induced and repressed ( 1 for 19 genes) (Table 5). The appearance of genes such as CCR5, EDG3, EDNRB and IL8RB strengthens families of genes already controlled by LPS in healthy subjects. We also observe an effect of LPS on the expression of neuropeptide receptors, BAI1, and HTR1A NTSR1. Conversely, LPS does not seem to affect the expression of GPRC5A, SSTR3, H963, EMR2 and $E M R 1$ genes in CD patients. 


\begin{tabular}{|c|c|c|c|c|}
\hline Assay ID & $\begin{array}{c}\text { Gene } \\
\text { symbol }\end{array}$ & Gene Name & T- & Average \\
TEST & $\Delta$ Ct \\
\hline Hs00173681_m1 & GPRC5A & retinoic acid induced 3 & 0.023 & 4.9 \\
\hline Hs00400624_m1 & GPR155 & G protein-coupled receptor 155 & 0.026 & 2.2 \\
\hline Hs00265633_s1 & SSTR3 & somatostatin receptor 3 & 0.005 & 1.6 \\
\hline Hs00664328_s1 & H963 & platelet activating receptor homolog & 0.027 & 1.5 \\
\hline Hs00173500_m1 & EDG2 & $\begin{array}{c}\text { endothelial differentiation, lysophosphatidic } \\
\text { acid GPCR 2 }\end{array}$ & 0.036 & -1.7 \\
\hline Hs00203752_m1 & EMR2 & egf-like module containing, mucin-like, & 0.006 & -1.8 \\
\hline Hs00261470_m1 & EMR3 & egf-like module containing, mucin-like, & 0.028 & -2.1 \\
\hline Hs00174298_m1 & CCR1 & chemormone receptor-like 3 & 0.016 & -2.2 \\
\hline Hs00271114_s1 & GPR35 & G protein-coupled receptor 35 & 0.005 & -2.4 \\
\hline Hs00181830_m1 & FPR1 & formyl peptide receptor 1 & 0.002 & -2.9 \\
\hline Hs00266213_s1 & CCR3 & chemokine (C-C motif) receptor 3 & 0.031 & -2.9 \\
\hline Hs00356604_m1 & CMKLR1 & chemokine-like receptor 1 & 0.034 & -3.0 \\
\hline Hs00356609_g1 & C5AR1 & complement component 5 receptor 1 (C5a & 0.006 & -3.7 \\
\hline Hs00266666_s1 & FPRL2 & formyl peptide receptor-like 2 & 0.011 & -3.9 \\
\hline Hs00175732_m1 & P2RY2 & purinergic receptor P2Y, G-protein coupled, 2 & 0.011 & -4.4 \\
\hline Hs00218495_m1 & GPR77 & G protein-coupled receptor 77 & 0.038 & -4.5 \\
\hline Hs00248078_m1 & GPR162 & $\begin{array}{c}\text { likely ortholog of mouse gene rich cluster, A } \\
\text { gene }\end{array}$ & 0.004 & -5.0 \\
\hline Hs00544894_m1 & GPBAR1 & G protein-coupled bile acid receptor 1 & 0.008 & -5.4 \\
\hline
\end{tabular}

Table 4. Genes differentially expressed between PBMCs of control subjects stimulated or not by LPS. Test ID: test Taqman Applied Biosystems identification; T-TEST: value $\mathrm{p}$ of the test of Student for paired data; Average of $\Delta \Delta \mathrm{Cts}$ : average of the difference of $\Delta \Delta \mathrm{Ct}\left(\Delta \mathrm{C} \mathrm{t}_{\text {healthy }}\right.$ $\Delta \mathrm{C} \mathrm{Ct}_{\text {healthy }}+\mathrm{LPS}$ ) for each individual. The average of $\Delta \Delta \mathrm{Cts}$ is positive for overexpressed genes and negative for under-expressed genes.

To search for genes regulated by LPS in a different manner in healthy individuals and patients with CD, we used a t test for unpaired data. Table 6 shows the three genes: P2RY2 gene is repressed by LPS in healthy subjects while remaining unaffected in CD patients, CCR5 gene is repressed only in CD patients, the gene GPR4 appears for a regulation in the opposite direction depending on whether LPS acts on PBMC from healthy individuals or CD patients. The difference of expression of GPR4 between patients and healthy becomes significant. It is interesting to note that the GPR4 gene was increased in PBMC of CD patients without LPS treatment. To these genes we might add the genes that appear only with the healthy or disease group like SSTR3, H963, GPRC5A, EMR2 and EMR3for the healthy or NTSR1, EDG3 and GPRAR for CD patients, but there is not enough statistical evidence at this level of the study to consider these genes differentially expressed between healthy subjects and patients. 
Inflammatory Bowel Disease G-Protein Coupled

Receptors (GPCRs) Expression Profiling with Microfluidic Cards

\begin{tabular}{|c|c|c|c|c|}
\hline Assay ID & $\begin{array}{c}\text { Gene } \\
\text { Symbol }\end{array}$ & Gene Name & T-TEST & $\begin{array}{l}\text { Average } \\
\Delta \Delta \text { Cts }\end{array}$ \\
\hline Hs00400624_m1 & GPR155 & G protein-coupled receptor 155 & 0.031 & 1.8 \\
\hline Hs00181777_m1 & BAI1 & brain-specific angiogenesis inhibitor 1 & 0.025 & -1.7 \\
\hline Hs00173500_m1 & EDG2 & $\begin{array}{c}\text { endothelial differentiation, } \\
\text { lysophosphatidic acid GPCR } 2\end{array}$ & 0.039 & -1.8 \\
\hline Hs00265014_s1 & HTR1A & $\begin{array}{l}\text { 5-hydroxytryptamine (serotonin) } \\
\text { receptor } 1 \mathrm{~A}\end{array}$ & 0.018 & -1.8 \\
\hline Hs00152917_m1 & CCR5 & chemokine (C-C motif) receptor 5 & 0.003 & -1.9 \\
\hline Hs00174304_m1 & IL8RB & interleukin 8 receptor, beta & 0.004 & -2.2 \\
\hline Hs00265090_s1 & ADRA2B & adrenergic, alpha-2B-, receptor & 0.041 & -2.2 \\
\hline Hs00266213_s1 & CCR3 & chemokine (C-C motif) receptor 3 & 0.007 & -2.3 \\
\hline Hs00356604_m1 & CMKLR1 & chemokine-like receptor 1 & 0.021 & -2.3 \\
\hline Hs00181830_m1 & FPR1 & formyl peptide receptor 1 & 0.034 & -2.6 \\
\hline Hs00174298_m1 & CCR1 & chemokine (C-C motif) receptor 1 & 0.007 & -3.4 \\
\hline Hs00173592_m1 & NTSR1 & neurotensin receptor 1 (high affinity) & 0.008 & -3.6 \\
\hline Hs00220561_m1 & GPR84 & G protein-coupled receptor 84 & 0.033 & -3.7 \\
\hline Hs00266666_s1 & FPRL2 & formyl peptide receptor-like 2 & 0.000 & -3.8 \\
\hline Hs00356609_g1 & C5AR1 & $\begin{array}{l}\text { complement component } 5 \text { receptor } 1 \\
\text { (C5a ligand) }\end{array}$ & 0.004 & -4.0 \\
\hline Hs00218495_m1 & GPR77 & G protein-coupled receptor 77 & 0.003 & -4.0 \\
\hline Hs00245464_s1 & EDG3 & $\begin{array}{l}\text { endothelial differentiation, sphingolipid } \\
\text { GPCR } 3\end{array}$ & 0.003 & -4.1 \\
\hline Hs00240747_m1 & EDNRB & endothelin receptor type B & 0.010 & -4.3 \\
\hline Hs00544894_m1 & GPBAR1 & G protein-coupled bile acid receptor 1 & 0.026 & -5.2 \\
\hline Hs00248078_m1 & GPR162 & $\begin{array}{c}\text { likely ortholog of mouse gene rich cluster, } \\
\text { A gene }\end{array}$ & 0.014 & -6.9 \\
\hline
\end{tabular}

Table 5. Genes differentially expressed between PBMC of CD patients stimulated or not by LPS. Test ID: Taqman Applied Biosystems identification test; T-TEST: value $p$ of the test of Student for paired data; Average of $\Delta \Delta \mathrm{Cts}$ : average of the difference of $\Delta \Delta \mathrm{Ct}\left(\Delta \mathrm{Ct} \mathrm{t}_{\mathrm{CD}}-\Delta \Delta \mathrm{C}\right.$ $\left.C t_{C D+L P S}\right)$ for each individual. The average of $\Delta \Delta \mathrm{Cts}$ is positive for overexpressed genes and negative if under-expressed.

\begin{tabular}{|c|c|c|c|c|}
\hline Assai ID & $\begin{array}{c}\text { Gene } \\
\text { Symbol }\end{array}$ & Gene Name & $\begin{array}{c}\text { T- } \\
\text { TEST }\end{array}$ & $\begin{array}{c}\text { Average } \\
\Delta \Delta \text { Cts }\end{array}$ \\
\hline Hs00175732_m1 & P2RY2 & $\begin{array}{c}\text { purinergic receptor P2Y, G-protein } \\
\text { coupled, 2 }\end{array}$ & 0.049 & 3.4 \\
\hline Hs00152917_m1 & CCR5 & chemokine (C-C motif) receptor 5 & 0.003 & -1.5 \\
\hline Hs00270999_s1 & GPR4 & G protein-coupled receptor 4 & 0.028 & -5.7 \\
\hline
\end{tabular}

Table 6. Genes differentially expressed in PBMCs stimulated by LPS between control and CD patients.

\subsection{Expression profiles in biopsies}

Biopsies from healthy subjects, CD, UC and IBS patients were analyzed. Data were obtained with the microfluidic card\#2 dedicated to GPCR transcriptome. The results presented were 
obtained from 11 biopsies taken from a sampling of heterogeneous individuals: one biopsy of healthy individuals, four zones of patients with inflammatory $\mathrm{CD}$ and a healthy area of a patient with CD, inflammatory zone 2 of patients with UC and a healthy area of a patient with UC, and 2 from patients with IBS. The results presented were obtained from 11 biopsies taken heterogeneous individuals: 1 biopsy of healthy individual only, 4 inflamed zones of CD patients and one healthy zone of CD patients, 2 inflamed zones of UC patients and a healthy zone of UC patient, and 2 inflamed zones of IBS patients.

Due to the heterogeneity and the small number of individuals studied, we tried to present here the most interesting results in spite of all possible combinations. It seemed wise to seek for receptors that expressed specifically in inflamed CD tissue relative to all other samples, biopsy of the healthy individual and those of patients with UC or IBS. This procedure is like comparing the inflammatory tissue of $\mathrm{CD}$ with background noise resulting from the combination of all other tissues. To do this, we used the same approach of comparing expression profiles of PBMCs from healthy subjects and patients with a Student test for unpaired data (a equal to 0.05 ) and the calculation of $\Delta \Delta \mathrm{Ct}$ averages of two classes $(\Delta \Delta \mathrm{Ct}=$ $(\Delta \mathrm{Ct}$ non-CD- $\Delta \mathrm{Ct} \mathrm{CD}))$. The genes were filtered with the criteria of an average of $\mathrm{Cts}$ lower than 37 and selected for $\Delta \Delta \mathrm{Ct}$ higher than 1.5. Thus Table 8 shows 37 genes differentially expressed between biopsies from inflamed zone of $\mathrm{CD}$ patients and all the other biopsies (healthy individual, healthy area of $\mathrm{CD}$ patient, areas of healthy and inflammatory UC patients and IBS). All 37 genes are overexpressed in CD.

Given the large number of genes revealed, we relied on the David software to highlight the functional categories appropriately represented in an expression profile. David is a Web application of NCBI that uses the NCBI GO terms (Gene Ontology) a vocabulary structured to describe role of genes and their products (The Gene Ontology Consortium, 2001). David interprets terms GO associated with differentially found genes and alternatively compares them with whole of functional categories of genes present on card\#2, alternately against the studied genome. Under "immune response", appeared a group of seven genes, including many chemokine receptors (ADORA1, BLR1, CNR2, CCR6, CCR7, CCR8, IL8RA, IL8RB). This group corresponds to an ontology enrichment of a factor 2 (8/33 compared to 49/362 in map 2). One can note the strong representation of genes related to neuropeptides, receptor proteins are 17 out of 33 ( 33 of the 37 gene list have a GO term). However, these receptors do not represent enrichment since they are 162 listed in this category.

We looked for genes characteristic of different types of inflammation of the intestine: IBS, UC and CD. To do this we compare the three groups of tissue two by two and used the criteria previously used to identify "differential" genes. Tables 8 to 11 represent the genes obtained. Table 11 shows a greater number of "differential" genes between inflamed zones between IBS patients and CD patients. All 19 genes are increasing in CD up to several orders of magnitude. These genes are composed in a large majority of neuropeptides receptors. There are also many orphan receptors, like the TAAR family ("Trace Amine Associated Receptor"), for which ligands are likely to have similarities with the metabolites of amino acids as neurotransmitters.

Table 12 shows 4 "differential" genes between UC and IBS: 3 orphan receptors are increased in UC biopsies whereas receptor of chemokine CCBP2 is reduced. Between biopsies of UC and CD (table 10), there are very few genes that are significantly "differently" expressed. Note that among four neuropeptide receptors, two are receptors for peptides from the brain (vasopressin and parathyroid hormone). These hormone receptors may reflect a special 
relationship of inflammatory bowel area with the central nervous system. Those genes are the significantly different between UC and CD.

\begin{tabular}{|c|c|c|c|c|}
\hline Assay ID & Gene Symbol & Gene Name & T-TEST & $\begin{array}{c}\text { Average } \\
\Delta \Delta \text { Cts }\end{array}$ \\
\hline Hs00609865_m1 & EDNRA & endothelin receptor type A & 0.002 & 6.6 \\
\hline Hs00174146_m1 & IL8RA & interleukin 8 receptor, alpha & 0.035 & 6.0 \\
\hline Hs00218495_m1 & GPR77 & G protein-coupled receptor 77 & 0.008 & 5.3 \\
\hline Hs00167241_m1 & HTR2A & 5-hydroxytryptamine (serotonin) receptor $2 \mathrm{~A}$ & 0.007 & 4.4 \\
\hline Hs00223340_m1 & GPR147 & G protein-coupled receptor 147 & 0.006 & 4.2 \\
\hline Hs00174304_m1 & IL8RB & interleukin 8 receptor, beta & 0.044 & 3.8 \\
\hline Hs00173855_m1 & GPR & putative $G$ protein coupled receptor & 0.002 & 3.6 \\
\hline Hs00176122_m1 & AVPR1A & arginine vasopressin receptor $1 \mathrm{~A}$ & 0.002 & 3.4 \\
\hline Hs00200681_m1 & ADMR & adrenomedullin receptor & 0.049 & 3.3 \\
\hline Hs00542381_m1 & GPR114 & G protein-coupled receptor 114 & 0.015 & 3.2 \\
\hline Hs00174895_m1 & PTHR1 & parathyroid hormone receptor 1 & 0.007 & 3.1 \\
\hline Hs00171054_m1 & CCR7 & chemokine (C-C motif) receptor 7 & 0.001 & 3.0 \\
\hline Hs00332805_m1 & MRGPRF & MAS-related GPR, member F & 0.003 & 3.0 \\
\hline Hs00736776_m1 & P2RY8 & purinergic receptor P2Y, G-protein coupled, 8 & 0.002 & 3.0 \\
\hline Hs00212116_m1 & GPRC5B & GPCR, family C, group 5, member B & 0.009 & 3.0 \\
\hline Hs00168765_m1 & PTGIR & prostaglandin I2 (prostacyclin) receptor (IP) & 0.027 & 2.9 \\
\hline Hs00174764_m1 & CCR8 & chemokine (C-C motif) receptor 8 & 0.016 & 2.9 \\
\hline Hs00361490_m1 & CNR2 & cannabinoid receptor 2 (macrophage) & 0.028 & 2.7 \\
\hline Hs00266671_s1 & FY & Duffy blood group & 0.040 & 2.7 \\
\hline Hs00391810_m1 & GPR116 & G protein-coupled receptor 116 & 0.009 & 2.6 \\
\hline Hs00237052_m1 & CXCR4 & chemokine (C-X-C motif) receptor 4 & 0.006 & 2.4 \\
\hline Hs00272624_s1 & CYSLTR1 & cysteinyl leukotriene receptor 1 & 0.040 & 2.4 \\
\hline Hs00174910_m1 & TSHR & thyroid stimulating hormone receptor & 0.030 & 2.4 \\
\hline Hs00168763_m1 & PTGFR & prostaglandin F receptor $(\mathrm{FP})$ & 0.028 & 2.3 \\
\hline Hs00187982_m1 & F2RL2 & coagulation factor II (thrombin) receptor-like 2 & 0.047 & 2.3 \\
\hline Hs00173499_m1 & EDG1 & $\begin{array}{l}\text { endothelial differentiation, sphingolipid } \\
\text { GPCR } 1\end{array}$ & 0.010 & 2.2 \\
\hline Hs00173527_m1 & BLR1 & $\begin{array}{c}\text { Burkitt lymphoma receptor 1, GTP binding } \\
\text { protein (chemokine (C-X-C motif) receptor 5) }\end{array}$ & 0.022 & 2.2 \\
\hline Hs00184657_m1 & BAI2 & brain-specific angiogenesis inhibitor 2 & 0.035 & 2.2 \\
\hline Hs00170665_m1 & SMO & smoothened homolog (Drosophila) & 0.043 & 2.1 \\
\hline Hs00262150_m1 & GPR124 & G protein-coupled receptor 124 & 0.026 & 2.1 \\
\hline Hs00274326_s1 & P2RY10 & purinergic receptor P2Y, G-protein coupled, 10 & 0.034 & 2.0 \\
\hline Hs00181231_m1 & ADORA1 & adenosine $\mathrm{A} 1$ receptor & 0.042 & 2.0 \\
\hline Hs00246222_s1 & NPY6R & neuropeptide Y receptor Y6 (pseudogene) & 0.026 & 2.0 \\
\hline Hs00168362_m1 & HTR2B & 5-hydroxytryptamine (serotonin) receptor 2B & 0.038 & 1.9 \\
\hline Hs00173787_m1 & CALCRL & calcitonin receptor-like & 0.028 & 1.9 \\
\hline Hs00169258_m1 & F2R & coagulation factor II (thrombin) receptor & 0.030 & 1.8 \\
\hline Hs00270873_s1 & AGTRL1 & angiotensin II receptor-like 1 & 0.026 & 1.8 \\
\hline Hs00171121_m1 & CCR6 & chemokine (C-C motif) receptor 6 & 0.009 & 1.8 \\
\hline
\end{tabular}

Table 7. Genes differentially expressed between biopsies of inflamed zone CD patients and biopsies of colon (healthy individual, healthy zone of the CD patient, healthy and inflamed zones of UC patients, inflamed zones of IBS patients). 


\begin{tabular}{|c|c|c|c|c|}
\hline Assay ID & $\begin{array}{c}\text { Gene } \\
\text { Symbol }\end{array}$ & Gene Name & $\begin{array}{c}\text { T- } \\
\text { TEST }\end{array}$ & $\begin{array}{c}\text { Average } \\
\Delta \Delta \text { Cts }\end{array}$ \\
\hline Hs00174146_m1 & IL8RA & interleukin 8 receptor, alpha & 0.002 & 10.8 \\
\hline Hs00218495_m1 & GPR77 & G protein-coupled receptor 77 & 0.035 & 8.4 \\
\hline Hs00220561_m1 & GPR84 & G protein-coupled receptor 84 & 0.023 & 7.9 \\
\hline Hs00174304_m1 & IL8RB & interleukin 8 receptor, beta & 0.025 & 6.1 \\
\hline Hs00223340_m1 & GPR147 & G protein-coupled receptor 147 & 0.010 & 5.9 \\
\hline Hs00271072_s1 & GPR23 & G protein-coupled receptor 23 & 0.043 & 5.8 \\
\hline Hs00181830_m1 & FPR1 & formyl peptide receptor 1 & 0.035 & 5.1 \\
\hline Hs00256749_s1 & P2RY13 & purinergic receptor P2Y, G-protein coupled, 13 & 0.012 & 4.0 \\
\hline Hs00266213_s1 & CCR3 & chemokine (C-C motif) receptor 3 & 0.034 & 3.7 \\
\hline Hs00261470_m1 & EMR3 & egf-like module containing, mucin-like, hormone & 0.040 & 3.6 \\
\hline Hs00269446_s1 & EDG6 & receptor-like 3 & 0.046 & 3.6 \\
\hline Hs00252658_s1 & CYSLTR2 & receptor 6 & 0.015 & 3.1 \\
\hline Hs00171054_m1 & CCR7 & cysteinyl leukotriene receptor 2 & 0.012 & 2.9 \\
\hline Hs00542381_m1 & GPR114 & G protein-coupled receptor 114 & 0.031 & 2.8 \\
\hline Hs00274326_s1 & P2RY10 & purinergic receptor P2Y, G-protein coupled, 10 & 0.027 & 2.4 \\
\hline Hs00252888_s1 & VN1R1 & vomeronasal 1 receptor 1 & 0.040 & 1.7 \\
\hline Hs00176738_m1 & MATK & megakaryocyte-associated tyrosine kinase & 0.041 & -1.3 \\
\hline Hs00191104_m1 & GPR37L1 & G-protein coupled receptor 37 like 1 & 0.039 & -4.8 \\
\hline
\end{tabular}

Table 8. Genes differentially expressed between biopsies of inflamed zone of CD patients, and biopsies of healthy individual and patients having IBS.

\begin{tabular}{|c|c|c|c|c|}
\hline Assay ID & Gene Symbol & Gene Name & T-TEST & Average $\Delta \Delta$ Cts \\
\hline Hs00266671_s1 & FY & Duffy blood group & 0.040 & 2.7 \\
\hline Hs00184657_m1 & BA12 & brain-specific angiogenesis inhibitor 2 & 0.035 & 2.2 \\
\hline Hs00181231_m1 & ADORA1 & adenosine A1 receptor & 0.042 & 2.0 \\
\hline
\end{tabular}

Table 9. Common genes differentially expressed between biopsies of inflamed zone and PBMCs of CD patients.

\begin{tabular}{|c|c|c|c|c|}
\hline Assay ID & Gene Symbol & Gene Name & $\begin{array}{c}\text { T- } \\
\text { TEST }\end{array}$ & Average $\Delta \Delta$ Cts \\
\hline Hs00174895_m1 & PTHR1 & parathyroid hormone receptor 1 & 0.001 & 3.9 \\
\hline Hs00176122_m1 & AVPR1A & Arginine vasopressin receptor 1A & 0.007 & 2.7 \\
\hline Hs00184657_m1 & BAI2 & brain-specific angiogenesis inhibitor 2 & 0.029 & 2.2 \\
\hline Hs00265081_s1 & ADRA2A & adrenergic, alpha-2A-, receptor & 0.044 & 2.1 \\
\hline Hs00174304_m1 & IL8RB & interleukin 8 receptor, beta & 0.004 & -2.2 \\
\hline Hs00266213_s1 & CCR3 & chemokine (C-C motif) receptor 3 & 0.007 & -2.3 \\
\hline Hs00181830_m1 & FPR1 & formyl peptide receptor 1 & 0.034 & -2.6 \\
\hline Hs00220561_m1 & GPR84 & G protein-coupled receptor 84 & 0.033 & -3.7 \\
\hline Hs00218495_m1 & GPR77 & G protein-coupled receptor 77 & 0.003 & -4.0 \\
\hline
\end{tabular}

Table 10. Genes differentially expressed between biopsies of inflamed zone of CD patients and biopsies of inflamed zone of UC patients. 
Inflammatory Bowel Disease G-Protein Coupled

Receptors (GPCRs) Expression Profiling with Microfluidic Cards

\begin{tabular}{|c|c|c|c|c|}
\hline Assay ID & $\begin{array}{c}\text { Gene } \\
\text { Symbol }\end{array}$ & Gene Name & $\begin{array}{c}\text { T- } \\
\text { TEST }\end{array}$ & $\begin{array}{c}\text { Average } \\
\Delta \Delta \text { Cts }\end{array}$ \\
\hline Hs00601815_s1 & TAAR9 & trace amine associated receptor 9 & 0.010 & 11.7 \\
\hline Hs00365019_s1 & MRGPRX2 & MAS-related GPR, member X2 & 0.009 & 11.4 \\
\hline Hs00265296_s1 & HTR1F & 5-hydroxytryptamine (serotonin) receptor 1F & 0.012 & 11.2 \\
\hline Hs00609865_m1 & EDNRA & endothelin receptor type A & 0.026 & 11.1 \\
\hline Hs00174146_m1 & IL8RA & interleukin 8 receptor, alpha & 0.006 & 11.1 \\
\hline Hs00265208_s1 & CHRM2 & cholinergic receptor, muscarinic 2 & 0.000 & 9.9 \\
\hline Hs00220561_m1 & GPR84 & G protein-coupled receptor 84 & 0.012 & 9.4 \\
\hline Hs00269590_s1 & TAAR5 & trace amine associated receptor 5 & 0.001 & 9.3 \\
\hline Hs00754695_s1 & MRGPRX3 & MAS-related GPR, member X3 & 0.043 & 8.8 \\
\hline Hs00265081_s1 & ADRA2A & adrenergic, alpha-2A-, receptor & 0.036 & 8.6 \\
\hline Hs00664049_s1 & GPR150 & G protein-coupled receptor 150 & 0.017 & 8.4 \\
\hline Hs00274365_s1 & TAAR2 & trace amine associated receptor 2 & 0.002 & 7.4 \\
\hline Hs00271072_s1 & GPR23 & G protein-coupled receptor 23 & 0.002 & 7.3 \\
\hline Hs00664166_s1 & GPR142 & G protein-coupled receptor 142 & 0.044 & 6.9 \\
\hline Hs00267157_s1 & MAS1 & MAS1 oncogene & 0.003 & 6.2 \\
\hline Hs00266671_s1 & FY & Duffy blood group & 0.030 & 5.8 \\
\hline Hs00271877_s1 & CD4R & Melanocortin 4 receptor & 0.046 & 5.1 \\
\hline Hs00269446_s1 & EDG6 & endothelial differentiation, G-protein-coupled & 0.029 & 4.5 \\
\hline Hs00168567_m1 & NPY2R & receptor 6 & 0.032 & 3.3 \\
\hline
\end{tabular}

Table 11. Genes differentially expressed between biopsies of inflamed zone of CD patients and IBS patients.

\begin{tabular}{|c|c|c|c|c|}
\hline Assay ID & $\begin{array}{c}\text { Gene } \\
\text { Symbol }\end{array}$ & Gene Name & T-TEST & $\begin{array}{c}\text { Average } \\
\Delta \Delta \text { Cts }\end{array}$ \\
\hline Hs00220561_m1 & GPR84 & G protein-coupled receptor 84 & 0.044 & 8.0 \\
\hline Hs00664166_s1 & GPR142 & G protein-coupled receptor 142 & 0.042 & 7.5 \\
\hline Hs00542396_m1 & GPR110 & G protein-coupled receptor 110 & 0.008 & 4.9 \\
\hline Hs00174299_m1 & CCBP2 & chemokine binding protein 2 & 0.039 & -2.8 \\
\hline
\end{tabular}

Table 12. Genes differentially expressed between biopsies of inflamed zone of FGD patients and UC patients.

\section{Conclusion}

Studying the expression of GPCRs in PBMCs has highlighted a number of deregulated genes in CD. In general, among these deregulated genes, the majority is accepted to be involved in mechanisms of inflammation or immune response. After a closer examination of their function, these genes appear to have an opposite contribution in the inflammatory process. Surprisingly, receptor expression is regulated more in favor of a repressor or suppressor effect of a malfunction of inflammatory cells rather than in a pro-inflammatory activity like SSTR5 whose role is to reduce intestinal inflammation.

Expression profiles of PBMC's GPCR distinguish CD patients from healthy donors are represented in Figure 10. The expression of a reduced number of genes makes it even clearly 
feasible to differentiate PBMCs from healthy individuals and CD patients (Figure 11). These receptors could be a signature for $C D$, but it remains necessary to test this group of genes with other known genes, for healthy and CD PBMCs, and so to check if clustering classifies correctly these samples. It would be also interesting to compare these profiles with those obtained from PBMCs of patients developing IBS or UC.

Our study activation of PBMCs by LPS shows that PBMCs are able to induce in vitro an immunizing response in answer to exposure to bacterial lipopolysaccharide of production and release in medium of TNF- $\alpha$, principal mediator of inflammatory answer. This activation of monocytes by LPS was amply described and used in routine way in laboratories to test capacity of monocytes to answer pathogenic microorganisms. Majority of human cells answer molecular signals of microbial invasion of installing locally mechanisms of defense, then by recruiting and activating specialized cells of immune system.

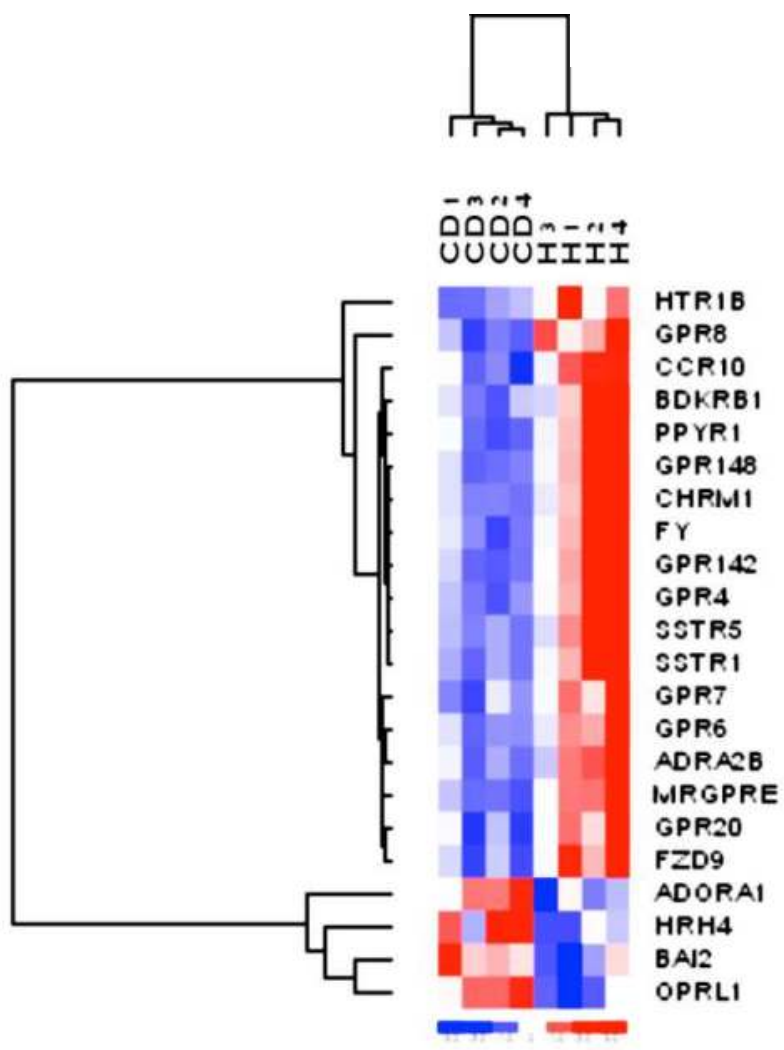

Fig. 10. Signature of GPCR expression in PBMCs from CD patients (CD) versus healthy donors $(\mathrm{H})$. Ascending hierarchic classification was carried out using the software Dchip (Li and Wong 2001) using a correlation matrix of distances and centroid grouping. The matrix of expression data is converted into a thermal colored map according to the relative level of expression of each gene. The colors range from blue to a high level of expression to red for a low level of expression through an intermediate white (values expressed in $\Delta \mathrm{Ct}$ ). 


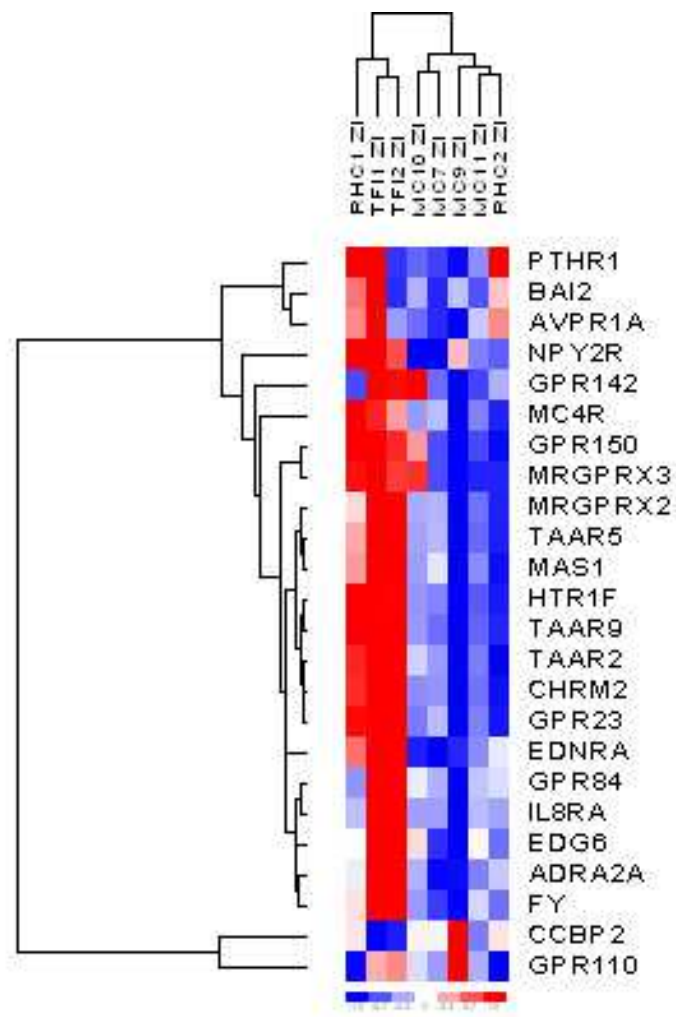

Fig. 11. Signature of expression of GPCRs in biopsies of CD patients (MCxx), UC patients (RHCxx) and IBS patients (TFIxx).

As has been described before, the recognition of TRL4 receptors on the surface of monocytes by a bacterial product such as LPS leads to a cascade of reactions within the cells and release of cytokines TNF- $\alpha$, but also IL-1, IL-3, I-6, IL-10, and colony stimulating factors (CSFs), chemokines such as IL-8 and macrophage inflammatory proteins (MIFs). The main mechanism underlying the induction of these proteins is at the level of transcription, particularly under the control of the transcription factor NF- $\kappa$ B. We studied here the effect of bacterial stimuli in an original way, first by examining its effect on the expression of almost all GPCRs, second using a macro-arrays technology by real-time PCR. Our results indicate that activation of PBMC by LPS is reflected mainly by a repression of GPCR expression. In a similar approach conducted with larger arrays, the same trend was observed i.e. LPS represses 1125 genes out of 1868 differentially expressed genes (Wurfel et al. 2005). Among the overexpressed genes, these authors note the presence of key players in the inflammatory response, primarily cytokines and chemokines. In our hands the only GPCR in the list of 15 genes selected in each category is the chemokine receptor 2 (CCR2) the 2nd most strongly repressed. If we noticed no decrease in CCR2, the experimental condition, origin of LPS, exposure time and concentration of LPS may explain this divergence of results. It is interesting to note that among genes repressed by LPS common to healthy individuals and 
CD patients, two families of receptor are represented: chemokine receptors (CCR1, CCR3, CMKLR1, C5AR1) and formylated peptides receptors (FPR1, FPRL2). The receptors involved in chemotaxis and recognition of bacterial peptides (CCR1, CMKLR1, RPF) have been extensively documented for their repression following LPS activation of PBMCs (Boldrick et al. 2002; Nau et al. 2002; Parker et al. 2004). Others observed similar expression profiles in PBMCs (Boldrick et al. 2002). In addition, they noticed that the induction and repression are LPS dose dependent and there are some differences in the profiles along the microorganism and their virulence, suggesting that some pathogens have developed strategies to foil the defense mechanism of host cells. However we observe a suppression of two other chemokine receptors: CCR3, known to have high affinity for eotaxin, a chemokine produced by eosinophil in broncho-alveolar fluid in the animal model of asthma (Jose, Griffiths-Johnson et al. 1994) and C5AR1 studied in neutrophil chemotaxis and linked to many diseases immune complex. Other receptors whose function is less known (EDG2, GPBAR1) and especially 2 orphan receptors (GPR155 one of rare genes activated by LPS and GPR162 repressed by more than 100 times in CD patients) could provide new elements in understanding the signaling pathways that control the inflammatory response.

The decrease in gene expression essential for the defense of an organism, while it is in contact with the invader, may seem paradoxical. One hypothesis is that these mechanisms of repression and induction of certain genes have a regulatory role for antigen-presenting cells (APC). This repression of genes, without which the massive amplification of defense systems quickly destroy infectious agents, allows the APC time to present antigens to T cells, not only at the site of infection but also in secondary lymphoid tissues.

It should be noted that parallel to repression of certain receptors, most of their ligands, cytokines and chemokines, are increased by LPS (Boldrick et al. 2002). This hypothesis reinforces the concept of immune defense mechanism tightly controlled and orchestrated at the transcriptional level as highlighted by studying expression profiles over time. Thus, in monocytes, LPS controls temporally and alternately increase and decrease of expression of different groups of gene (Sharif et al. 2007). In the context of a specific program of control of gene expression, it is not surprising that the time, the origin and the dose of LPS are factors that influence the expression profile. It is interesting to note that in the work of Sharif and coll., 4 receptors of our repertory are among the 72 genes controlled by LPS: after 1 hour of exposure, only ADORA1 is slightly increased but returns to its original level at 4 hours, after four hours, while CCR7 is increased CCR2 and CXR4 are repressed. Our results for these genes obtained after 2 hours 30 of exposure are compatible and consistent with those described before (Sharif et al. 2007). In Table 6 are represented the 3 receptors whose expression varies significantly for CD patients. Why and how genes are regulated in the context of healthy individuals or with the disease and how they are connected to other receptors deregulated in $\mathrm{CD}$ patients, are questions difficult to be answered at this level of study. However, the large number of genes controlled by LPS in both healthy subjects and CD patients, compared to three genes differentially controlled, suggests that PBMC from the two populations have the capacity to respond very similarly to LPS activation, suggesting that CD patients PBMCs are only moderately disturbed in response to a bacterial infection. However, we can not exclude that one of the 3 receptors that differentiate two groups of individuals in response to bacterial stimuli, could control a signaling pathway involved, directly or indirectly, in CD. For example, disability and loss of immunological tolerance vis-à-vis certain species of commensal bacteria in the intestine is characteristic of CD 
patients and are often put forward to explain the chronicity of the inflammatory state (Sartor 2003). The expression profiles of GPCR in inflamed zones of Crohn patients clearly suggest a close relationship between the inflammatory process and the nervous system. Our results have shown unequivocally chemokine receptors (ADORA1, BLR1, CCR6, CCR7, CCR8, IL8RA, IL8RB) many neuropeptide receptors and neurotransmitter in the disease. Neuropeptide receptors and neurotransmitter occupy an essential place in the nervous system to ensure the function of the intestinal wall. The nervous system is complex: the autonomous nervous system consists of a network of nerve fibers connected to the plexus that connect the different layers of the wall and sympathetic and parasympathetic fibers that make synapses in small intramural ganglia. The autonomous nervous system ensures glandular secretion, vasodilation and vasoconstriction, and motility of smooth muscle fibers. The colon wall is also controlled by the vegetative nervous system under the control of the hypothalamic-adrenal-hypophysio-surrenal axis. It is through him that emotions, stress and fatigue affect the functioning of the digestive system (Taylor \& Keely 2007).

The presence of chemokine receptors, neuropeptides and neurotransmitters suggests a close relationship and communication between nerve cells, the intestinal lining cells and immune cells in the inflammatory zone. These links are illustrated by the endocrine cells, for example, the colonic epithelium that secrete polypeptide hormones and neurotransmitters such as gastrin, cholecystokinin (CCK), VIP (vasoactive intestinal peptide), substance P, bombesin and somatostatin and serotonin, which also act as neurotransmitters. If the effect of the ligands is relatively well documented in all functions related to the nervous system, transmission potential, secretion, muscle contractility, the role of receptors is more complex. The increase in receptors in the inflammatory tissue of $C D$ is consistent with a general increase in neuronal signaling, described in the literature in terms of neuropeptides and neurotransmitters. At this stage of the study, interpretation of the increase in these receptors and their role in the inflammation is difficult without information on the characteristics of cells in which they are overexpressed.

These increases can be linked to altered activity of nerve cells under the influence of inflammatory mediators or a nervous system response to restore tissue to a normal state. The histology of the intestinal mucosa, as we observed on our CD biopsies, must be accompanied by a remodeling of the enteric system so that it can perform its functions. It is a set of elements that are responsible for these changes: neuronal plasticity, all of these neuronal modulations, changes in morphology, the number and development of new dendrites for connective, but the emergence of new nerve cells (Geboes \& Collins 1998). The increase of certain nerve cells may explain the increase in receptors. Enterochromaffin cells contain many neuroactive substances such as serotonin, bradykinin, tachykinin and prostaglandin that are released by multiple stimuli, mechanical, chemical and nervous. The release of serotonin, which has many roles (such as the increase in intestinal motility, vasoconstriction, synaptic transmission), is controlled at the level of enterochromaffin cells by receptors some of which have a stimulatory activity (HTR1, HTR2, MCR3) while others have an inhibitory activity (HTR3, type purinergic receptor P2Y, histamine, neurokinin, somatostatin). In these cells, two receptors HTR2 A and B increased in Crohn's disease, have a role rather amplifier of the disease. It would be the same level of sensory nerves that express a wide range of receptor on their surface. Neuronal activity is controlled mainly by receptor of natural substances such as VIP or substance $\mathrm{P}$, but the activity can be altered by the presence of inflammatory products (serotonin, bradykinin, prostaglandin leukotriene, 
ATP) and usually results in hyper excitability. Generally, treatment uses antagonists of these receptors (Hansen 2003).

All nerve cells do not have the same contribution in the development of the disease. For example, in terms of motility disorders, due to alterations in signal transmission at synapses of the enteric nerves, it was shown that motility of the intestine is controlled by the adrenergic sympathetic fibers that decrease while the parasympathetic fibers stimulate the cholinergic (Smith \& Smid 2005). Studies show that agents which promote parasympathetic activity also tend to reduce the severity of the disease, and conversely for sympathetic activity (Miceli \& Jacobson 2003). It would be interesting to know the repertoire of these receptors in nerve cells and identify those that are deregulated in order to use agonists or antagonists to restore gut motility.

Results reported here are encouraging nevertheless they remain preliminary. It will be necessary to analyze a larger number of samples, identify exactly the biopsy position in the colon and obtain relevant information on individuals before hoping to get molecular signatures of the different types of bowel diseases. In a therapeutic point of view, our results on the transcriptome of GPCRs from Crohn's disease biopsies offer a wide range of potential therapeutic targets, for functions as diverse as those related to the immune response, hormonal regulations, transfers of nervous information nerve, or blood clotting.

\section{Acknowledgment}

The study was supported by a grant from ACI 2002, MNRT, CNRS-INSERM-CEA, Pathologies-RCPG-Médicaments France. Nathalie Taquet was supported by a grant from FERRING laboratories (Gentilly, France) and Jean-Marie Reimund received a grant from UCB Laboratories, France.

\section{References}

Andres, P. G. \& Friedman, L. S. (1999). Epidemiology and the natural course of inflammatory bowel disease. Gastroenterol Clin North Am, Vol.28 N² (Jun), pp. 255-281

Baker, P. E., Fahey, J. V. \& Munck, A. (1981). Prostaglandin inhibition of T-cell proliferation is mediated at two levels. Cell Immunol, Vol.61 N¹ (Jun), pp. 52-61

Baldassano, R. N. \& Piccoli, D. A. (1999). Inflammatory bowel disease in pediatric and adolescent patients. Gastroenterol Clin North Am, Vol.28 N² (Jun), pp. 445-458

Boldrick, J. C., Alizadeh, A. A., Diehn, M., Dudoit, S., Liu, C. L., Belcher, C. E., Botstein, D., Staudt, L. M., Brown, P. O. \& Relman, D. A. (2002). Stereotyped and specific gene expression programs in human innate immune responses to bacteria. Proc Natl Acad Sci U S A, Vol.99 N² (Jan 22), pp. 972-977

Burczynski, M. E., Peterson, R. L., Twine, N. C., Zuberek, K. A., Brodeur, B. J., Casciotti, L., Maganti, V., Reddy, P. S., Strahs, A., Immermann, F., Spinelli, W., Schwertschlag, U., Slager, A. M., Cotreau, M. M. \& Dorner, A. J. (2006). Molecular classification of Crohn's disease and ulcerative colitis patients using transcriptional profiles in peripheral blood mononuclear cells. J Mol Diagn, Vol.8 №1 (Feb), pp. 51-61

Chomczynski, P. \& Sacchi, N. (1987). Single-step method of RNA isolation by acid guanidinium thiocyanate-phenol-chloroform extraction. Anal Biochem, Vol.162 No1 (Apr), pp. 156-159 
Dieckgraefe, B. K., Stenson, W. F., Korzenik, J. R., Swanson, P. E. \& Harrington, C. A. (2000). Analysis of mucosal gene expression in inflammatory bowel disease by parallel oligonucleotide arrays. Physiol Genomics, Vol.4 N¹ (Nov 9), pp. 1-11

Elson, C. O., Sartor, R. B., Tennyson, G. S. \& Riddell, R. H. (1995). Experimental models of inflammatory bowel disease. Gastroenterology, Vol.109 N4 (Oct), pp. 1344-1367

Geboes, K. \& Collins, S. (1998). Structural abnormalities of the nervous system in Crohn's disease and ulcerative colitis. Neurogastroenterol Motil, Vol.10 N³ (Jun), pp. 189202

Hansen, M. B. (2003). The enteric nervous system I: organisation and classification. Pharmacol Toxicol, Vol.92 N³ (Mar), pp. 105-113

Lawrance, I. C., Fiocchi, C. \& Chakravarti, S. (2001). Ulcerative colitis and Crohn's disease: distinctive gene expression profiles and novel susceptibility candidate genes. Hum Mol Genet, Vol.10 No5 (Mar 1), pp. 445-456

Luther, S. A. \& Cyster, J. G. (2001). Chemokines as regulators of T cell differentiation. Nat Immunol, Vol.2 N² (Feb), pp. 102-107

Matsuura, T., West, G. A., Youngman, K. R., Klein, J. S. \& Fiocchi, C. (1993). Immune activation genes in inflammatory bowel disease. Gastroenterology, Vol.104 No2 (Feb), pp. 448-458

Miceli, P. C. \& Jacobson, K. (2003). Cholinergic pathways modulate experimental dinitrobenzene sulfonic acid colitis in rats. Auton Neurosci, Vol.105 No1 (Apr 30), pp. 16-24 1566-0702 (Print)

Nau, G. J., Richmond, J. F., Schlesinger, A., Jennings, E. G., Lander, E. S. \& Young, R. A. (2002). Human macrophage activation programs induced by bacterial pathogens. Proc Natl Acad Sci U S A, Vol.99 N³ (Feb 5), pp. 1503-1508

Onuffer, J. J. \& Horuk, R. (2002). Chemokines, chemokine receptors and small-molecule antagonists: recent developments. Trends Pharmacol Sci, Vol.23 №10 (Oct), pp. 459467

Parker, L. C., Whyte, M. K., Vogel, S. N., Dower, S. K. \& Sabroe, I. (2004). Toll-like receptor (TLR)2 and TLR4 agonists regulate CCR expression in human monocytic cells. J Immunol, Vol.172 N8 (Apr 15), pp. 4977-4986

Podolsky, D. K. (2002). Inflammatory bowel disease. N Engl J Med, Vol.347 N6 (Aug 8), pp. 417-429

Rockett, J. C., Burczynski, M. E., Fornace, A. J., Herrmann, P. C., Krawetz, S. A. \& Dix, D. J. (2004). Surrogate tissue analysis: monitoring toxicant exposure and health status of inaccessible tissues through the analysis of accessible tissues and cells. Toxicol Appl Pharmacol, Vol.194 N² (Jan 15), pp. 189-199

Sartor, R. B. (2003). Targeting enteric bacteria in treatment of inflammatory bowel diseases: why, how, and when. Curr Opin Gastroenterol, Vol.19 N4 (Jul), pp. 358-365

Satsangi, J., Parkes, M., Louis, E., Hashimoto, L., Kato, N., Welsh, K., Terwilliger, J. D., Lathrop, G. M., Bell, J. I. \& Jewell, D. P. (1996). Two stage genome-wide search in inflammatory bowel disease provides evidence for susceptibility loci on chromosomes 3, 7 and 12. Nat Genet, Vol.14 N² (Oct), pp. 199-202

Schroeder, A., Mueller, O., Stocker, S., Salowsky, R., Leiber, M., Gassmann, M., Lightfoot, S., Menzel, W., Granzow, M. \& Ragg, T. (2006). The RIN: an RNA integrity number for assigning integrity values to RNA measurements. BMC Mol Biol, Vol.7 pp. 3 14712199 (Electronic) 
Sharif, O., Bolshakov, V. N., Raines, S., Newham, P. \& Perkins, N. D. (2007). Transcriptional profiling of the LPS induced NF-kappaB response in macrophages. BMC Immunol, Vol.8 pp. 1

Sirover, M. A. (1999). New insights into an old protein: the functional diversity of mammalian glyceraldehyde-3-phosphate dehydrogenase. Biochim Biophys Acta, Vol.1432 No2 (Jul 13), pp. 159-184

Smith, A. S. \& Smid, S. D. (2005). Impaired capsaicin and neurokinin-evoked colonic motility in inflammatory bowel disease. J Gastroenterol Hepatol, Vol.20 N5 (May), pp. 697-704

Tatton, W. G., Chalmers-Redman, R. M., Elstner, M., Leesch, W., Jagodzinski, F. B., Stupak, D. P., Sugrue, M. M. \& Tatton, N. A. (2000). Glyceraldehyde-3-phosphate dehydrogenase in neurodegeneration and apoptosis signaling. J Neural Transm Suppl N60 pp. $77-100$

Taylor, C. T. \& Keely, S. J. (2007). The autonomic nervous system and inflammatory bowel disease. Auton Neurosci, Vol.133 N¹ (Apr 30), pp. 104-114

Thelen, M. (2001). Dancing to the tune of chemokines. Nat Immunol, Vol.2 No2 (Feb), pp. 129-134

Warner, E. E. \& Dieckgraefe, B. K. (2002). Application of genome-wide gene expression profiling by high-density DNA arrays to the treatment and study of inflammatory bowel disease. Inflamm Bowel Dis, Vol.8 N² (Mar), pp. 140-157

Wurfel, M. M., Park, W. Y., Radella, F., Ruzinski, J., Sandstrom, A., Strout, J., Bumgarner, R. E. \& Martin, T. R. (2005). Identification of high and low responders to lipopolysaccharide in normal subjects: an unbiased approach to identify modulators of innate immunity. J Immunol, Vol.175 N4 (Aug 15), pp. 2570-2578 


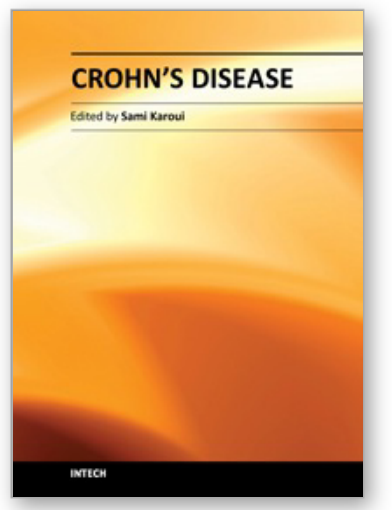

\author{
Crohn's Disease \\ Edited by Dr. Sami Karoui
}

ISBN 978-953-307-811-3

Hard cover, 210 pages

Publisher InTech

Published online 13, January, 2012

Published in print edition January, 2012

In this book, several important points regarding Crohn's disease are discussed. In the first section, we focus on etiopathogeny of Crohn's disease and the recent advances in our overall understanding of the disease specifically, the role of the gut epithelium, alterations of the epithelial crypts, and the roles of the different cytokines in the pathophysiology of Crohn's disease. In the second section, a diagnosis of Crohn's disease is discussed. Another particular area of focus is in the diagnosis of intestinal tuberculosis, and the role of mycobacterium avium in Crohn's disease. In the third and final section, the management of Crohn's disease is discussed, with a focus on recent evidence-based medicine recommendations.

\title{
How to reference
}

In order to correctly reference this scholarly work, feel free to copy and paste the following:

Nathalie Taquet, Claude Philippe, Jean-Marie Reimund and Christian D. Muller (2012). Inflammatory Bowel Disease G-Prote in Coupled Receptors (GPCRs) Expression Profiling with Microfluidic Cards, Crohn's Disease, Dr. Sami Karoui (Ed.), ISBN: 978-953-307-811-3, InTech, Available from:

http://www.intechopen.com/books/crohn-s-disease/inflammatory-bowel-disease-g-prote-in-coupled-receptorsgpcrs-expression-profiling-with-microfluidic

\section{INTECH}

open science | open minds

\section{InTech Europe}

University Campus STeP Ri Slavka Krautzeka 83/A 51000 Rijeka, Croatia Phone: +385 (51) 770447 Fax: +385 (51) 686166 www.intechopen.com

\section{InTech China}

Unit 405, Office Block, Hotel Equatorial Shanghai

No.65, Yan An Road (West), Shanghai, 200040, China 中国上海市延安西路65号上海国际贵都大饭店办公楼 405 单元

Phone: +86-21-62489820

Fax: +86-21-62489821 
(C) 2012 The Author(s). Licensee IntechOpen. This is an open access article distributed under the terms of the Creative Commons Attribution 3.0 License, which permits unrestricted use, distribution, and reproduction in any medium, provided the original work is properly cited. 